\title{
Synthesis and Structural Characterisation of
}

\section{$\left[\operatorname{Ir}_{4}(\mathrm{CO})_{8}\left(\mathrm{CH}_{3}\right)\left(\mu_{4}-\eta^{3}-\mathrm{Ph}_{2} \mathbf{P C C P h}\right)\left(\mu-\mathrm{PPh}_{2}\right)\right]$ and of the Carbonylation}

Product $\left[\operatorname{Ir}_{4}(\mathbf{C O}){ }_{8}\left\{\mathrm{C}(\mathrm{O}) \mathrm{CH}_{3}\right\}\left(\mu_{4}-\eta^{3}-\mathrm{Ph}_{2} \mathbf{P C C P h}\right)\left(\mu-\mathbf{P P h}_{2}\right)\right]$;

First Evidence for the Formation of a CO Cluster Adduct

\section{before CO Insertion}

\author{
Dario Braga $^{\mathrm{a}}$, Fred Y. Fujiwara ${ }^{\mathrm{b}}$, Fabrizia Grepioni ${ }^{\mathrm{a}}$, Regina M.S. Pereira ${ }^{\mathrm{b}}$, \\ and Maria D. Vargas ${ }^{\mathrm{b}^{*}}$ \\ a Dipartimento di Chimica “G.Ciamician”, Universitá degli Studi di Bologna, Via
}

Selmi 2, 40126 Bologna, Italy

binstituto de Química, Universidade Estadual de Campinas, CP 6154, 13083-970 Campinas, SP - Brazil

A desprotonação do cluster $\left[(\mu-\mathrm{H}) \operatorname{Ir} 4(\mathrm{CO})_{10}\left(\mu-\mathrm{PPh}_{2}\right)\right], 1$, leva à formação de $\left[\operatorname{Ir}_{4}(\mathrm{CO}) 10(\mu-\right.$ $\left.\left.\mathrm{PPh}_{2}\right)\right]^{-}$que reage com $\mathrm{Ph}_{2} \mathrm{PCCPh}$ e $\mathrm{CH}_{3} \mathrm{I}$ para dar $\left[\mathrm{Ir}_{4}(\mathrm{CO})_{8}\left(\mathrm{CH}_{3}\right)\left(\mu_{4}-\eta^{3}-\mathrm{Ph}_{2} \mathrm{PCCPh}\right)\left(\mu-\mathrm{PPh}_{2}\right)\right], 2$ $(34 \%)$, além de $\left[\operatorname{Ir}_{4}(\mathrm{CO})_{9}\left(\mu_{3}-\eta^{3}-\mathrm{Ph}_{2} \mathrm{PC}(\mathrm{H}) \mathrm{CPh}\right)\left(\mu-\mathrm{PPh}_{2}\right)\right]$ e $\left[(\mu-\mathrm{H}) \operatorname{Ir}_{4}(\mathrm{CO}) 9\left(\mathrm{Ph}_{2} \mathrm{PC} \equiv \mathrm{CPh}\right)-\right.$ $\left.\left(\mu-\mathrm{PPh}_{2}\right)\right]$. O composto 2 , caracterizado por uma análise de difração de raios-X, contem um arranjo metálico na forma de uma borboleta, com o ligante $\mathrm{Ph}_{2} \mathrm{PCCPh}$ interagindo com os quatro átomos de Ir e a metila ligada de modo terminal. A carbonilação de 2 resulta, inicialmente $\left(20 \mathrm{~min}, 25^{\circ} \mathrm{C}\right)$, na formação de um produto de adição ao poliedro metálico que, de acordo com estudos de espectroscopia de RMN de ${ }^{31} \mathrm{P}\left\{{ }^{1} \mathrm{H}\right\}$ e ${ }^{13} \mathrm{C}\left\{{ }^{1} \mathrm{H}\right\}$ a várias temperaturas, existe na forma de dois isomeros $4 \mathrm{~A}$ and $\mathbf{4 B}(8: 1)$ que diferem com relação à posição do grupo metila, e em seguida $\left(40^{\circ} \mathrm{C}\right.$, $7 \mathrm{~h})$, à formação do produto de inserção de $\mathrm{CO}$, $\left[\operatorname{Ir}_{4}(\mathrm{CO})_{8}\left\{\mathrm{C}(\mathrm{O}) \mathrm{CH}_{3}\right\}\left(\mu_{4}-\eta^{3}-\mathrm{Ph}_{2} \mathrm{PCCPh}\right)\left(\mu-\mathrm{PPh}_{2}\right)\right]$, 5. A carbonilação é reversível em ambos os estágios. A estrutura molecular de $\mathbf{5}$ é semelhante à de 2, com uma acila no lugar da metila. As reações de 2 com $\mathrm{PPh}_{3}$ e $\mathrm{P}(\mathrm{OMe})_{3}$ resultam nos produtos de substituição de $\mathrm{CO},\left[\mathrm{Ir}_{4}(\mathrm{CO})_{7} \mathrm{~L}\left(\mathrm{CH}_{3}\right)\left(\mu_{4}-\eta^{3}-\mathrm{Ph}_{2} \mathrm{PCCPh}\right)\left(\mu-\mathrm{PPh}_{2}\right)\right]\left(\mathrm{L}=\mathrm{PPh}_{3}, 6\right.$ e $\mathrm{P}(\mathrm{OMe})_{3} 7$, respectivamente, ao invés dos produtos esperados de inserção de CO. Segundo estudos de RMN $\mathrm{de}^{1} \mathrm{H}$ e ${ }^{31} \mathrm{P}\left\{{ }^{1} \mathrm{H}\right\}$, o composto 6 existe na forma de dois isômeros (1:1) que diferem com relação à posição da $\mathrm{PPh} 3$.

Deprotonation of $\left[(\mu-\mathrm{H}) \operatorname{Ir}_{4}(\mathrm{CO})_{10}\left(\mu-\mathrm{PPh}_{2}\right)\right]$, 1, gives $\left[\mathrm{Ir}_{4}(\mathrm{CO})_{10}\left(\mu-\mathrm{PPh}_{2}\right)\right]^{-}$that reacts with $\mathrm{Ph}_{2} \mathrm{PCCPh}$ and $\mathrm{CH}_{3} \mathrm{I}$ to afford $\left[\mathrm{Ir}_{4}(\mathrm{CO})_{8}\left(\mathrm{CH}_{3}\right)\left(\mu_{4}-\eta^{3}-\mathrm{Ph}_{2} \mathrm{PCCPh}\right)\left(\mu-\mathrm{PPh}_{2}\right)\right], 2$ (34\%), besides $\left[\operatorname{Ir}_{4}(\mathrm{CO}) 9\left(\mu_{3}-\eta^{3}-\mathrm{Ph}_{2} \mathrm{PC}(\mathrm{H}) \mathrm{CPh}\right)\left(\mu-\mathrm{PPh}_{2}\right)\right]$ and $\left[(\mu-\mathrm{H}) \operatorname{Ir}_{4}(\mathrm{CO}){ }_{9}\left(\mathrm{Ph}_{2} \mathrm{PC} \equiv \mathrm{CPh}\right)\left(\mu-\mathrm{PPh}_{2}\right)\right]$. Compound 2 was characterised by a single crystal X-ray diffraction analysis and exhibits a flat butterfly of metal atoms, with the $\mathrm{Ph}_{2} \mathrm{PCCPh}$ ligand interacting with all four Ir atoms and the methyl group bonded terminally to a wingtip Ir atom. Carbonylation of 2 yields initially $\left(25^{\circ} \mathrm{C}, 20 \mathrm{~min}\right)$ a $\mathrm{CO}$ addition product that, according to $\mathrm{VT}{ }^{31} \mathrm{P}\left\{{ }^{1} \mathrm{H}\right\}$ and ${ }^{13} \mathrm{C}\left\{{ }^{1} \mathrm{H}\right\}$ studies, exists in solution in the form of two isomers $4 \mathrm{~A}$ and $\mathbf{4 B}(8: 1)$, and then $\left(40{ }^{\circ} \mathrm{C}, 7 \mathrm{~h}\right)$, the $\mathrm{CO}$ insertion product $\left[\mathrm{Ir}_{4}(\mathrm{CO}){ }_{8}\left\{\mathrm{C}(\mathrm{O}) \mathrm{CH}_{3}\right\}\right.$ $\left.\left(\mu_{4}-\eta^{3}-\mathrm{Ph}_{2} \mathrm{PCCPh}\right)\left(\mu-\mathrm{PPh}_{2}\right)\right], \mathbf{5}$. The molecular structure of $\mathbf{5}$, established by an X-ray analysis, is similar to that of $\mathbf{2}$, except for the acyl group that remains bound to the same Ir atom. The process is reversible at both stages. Treatment of 2 with $\mathrm{PPh}_{3}$ and $\mathrm{P}(\mathrm{OMe})_{3}$ affords the $\mathrm{CO}$ substitution products $\left[\mathrm{Ir}_{4}(\mathrm{CO})_{7} \mathrm{~L}\left(\mathrm{CH}_{3}\right)\left(\mu_{4}-\eta^{3}-\mathrm{Ph}_{2} \mathrm{PCCPh}\right)\left(\mu-\mathrm{PPh}_{2}\right)\right]\left(\mathrm{L}=\mathrm{PPh}_{3}, 6\right.$ and $\left.\mathrm{P}(\mathrm{OMe})_{3}, 7\right)$, instead of the expected $\mathrm{CO}$ inserted products. According to the ${ }^{1} \mathrm{H}$ and ${ }^{31} \mathrm{P}\left\{{ }^{1} \mathrm{H}\right\}$ NMR studies, the $\mathrm{PPh}_{3}$ derivative $\mathbf{6}$ exists in the form of two isomers (1:1) that differ with respect to the position of this ligand.

Keywords: migratory insertion, iridium carbonyl clusters, alkyl clusters, carbonylation 


\section{Introduction}

The isolobal analogy between the $\mathrm{H}$ and $\mathrm{R}$ fragments ${ }^{1}$ has been very little explored in carbonyl cluster chemistry, although it has been shown to hold true for a number of mononuclear compounds. Structurally analogous hydride and alkyl clusters are rather rare in the literature. To our knowledge, the following series of compounds, $\left[\mathrm{HIr}_{4}(\mathrm{CO})_{11}\right]^{-(2)}$ and $\left[\mathrm{Ir}_{4}(\mathrm{CO})_{11}\left(\mathrm{CH}_{2} \mathrm{COOMe}\right)\right]^{-(3)}$, $\left[\mathrm{H}_{2} \mathrm{Ir}_{4}(\mathrm{CO})_{10}\right]^{2-}(4)$ and $\left[\mathrm{Ir}_{4}(\mathrm{CO})_{10}\left(\mathrm{CH}_{2} \mathrm{COOMe}\right)_{2}\right]^{2-}$ and $\left[\mathrm{Ru}_{6} \mathrm{C}(\mathrm{CO})_{16}\left(\mathrm{CH}_{3}\right)\right]^{-(5)}$ and $\left[\mathrm{HRu}_{6} \mathrm{C}(\mathrm{CO})_{16}\right]^{-(6)}$ are the only documented examples. It is probably significant that these hydride clusters contain terminal hydride ligands, which are very rarely encountered in cluster chemistry, instead of commonly found bridging hydrides 7 . This observation would explain the scarcity of alkyl carbonyl clusters in the literature. We recently reported the synthesis $^{8}$ and the molecular structure ${ }^{9}$ of the only other $\operatorname{Ir}_{4}$ cluster with a terminal hydride ligand, $\left[\operatorname{HIr}_{4}(\mathrm{CO})_{9}\left(\mu_{4}-\eta^{3}-\right.\right.$ $\left.\left.\mathrm{Ph}_{2} \mathrm{PCCPh}\right)\left(\mu-\mathrm{PPh}_{2}\right)\right]$, via the deprotonation of $[(\mu-\mathrm{H})-$ $\left.\operatorname{Ir}_{4}(\mathrm{CO})_{10}\left(\mu-\mathrm{PPh}_{2}\right)\right]$, reaction in situ with $\mathrm{Ph}_{2} \mathrm{PC} \equiv \mathrm{CPh}$, followed by reprotonation. We therefore attempted to produce the analogous methyl containing cluster, by methylating, instead of protonating, the mixture above.

Carbon monoxide insertion into metal alkyl or aryl bonds is a textbook reaction ${ }^{10}$, but this process in alkyl and aryl containing carbonyl clusters has only been documented in rare cases ${ }^{5,11-13}$. We have recently described the first study involving the carbonylation of a phenyl group co-ordinated to a cluster, $\left[\operatorname{Ir}_{4}(\mathrm{CO})_{8}\left(\eta^{1}-\mathrm{Ph}\right)\left(\mu_{3}-\eta^{3}\right.\right.$ $\left.\mathrm{PhPC}(\mathrm{H}) \mathrm{CPh})\left(\mu-\mathrm{PPh}_{2}\right)\right]^{12}$. In this report, we describe the synthesis and characterisation of the methyl containing cluster $\left[\operatorname{Ir}_{4}(\mathrm{CO})_{8}\left(\mathrm{CH}_{3}\right)\left(\mu_{4}-\eta^{3}-\mathrm{Ph}_{2} \mathrm{PCCPh}\right)\left(\mu-\mathrm{PPh}_{2}\right)\right]$ and its facile quantitative carbonylation to the isostructural acyl product $\quad\left[\mathrm{Ir}_{4}(\mathrm{CO})_{8}\left\{\mathrm{C}(\mathrm{O}) \mathrm{CH}_{3}\right\}\left(\mu_{4}-\eta^{3}-\mathrm{Ph}_{2} \mathrm{PCCPh}\right)(\mu-\right.$ $\left.\mathrm{PPh}_{2}\right)$ ] via a $\mathrm{CO}$ addition intermediate, characterised by multinuclear NMR spectroscopy. To our knowledge, this is the first example of a fully characterised stepwise reversible process involving a $\mathrm{CO}$ addition and $\mathrm{CO}$ insertion into a M-Calkyl bond in a cluster compound. A preliminary communication of part of this work has appeared ${ }^{14}$.

\section{Experimental}

\section{General}

All manipulations and reactions were carried out under dry argon, unless otherwise specified, using standard Schlenk techniques. $\mathrm{CH}_{2} \mathrm{Cl}_{2}$ was dried over $\mathrm{CaH}_{2}$, hexane and toluene over sodium and THF over potassium. Solvents were freshly distilled under Ar and freed from dissolved oxygen, where compatible, by freeze degassing before use. BuLi (1.6 M hexane solution), $\mathrm{CH}_{3} \mathrm{I}$ and ${ }^{13} \mathrm{CH}_{3} \mathrm{I}$ (Aldrich) were used as received, $\mathrm{Ph}_{2} \mathrm{PC} \equiv \mathrm{CPh}^{15},\left[(\mu-\mathrm{H}) \mathrm{Ir}_{4}(\mathrm{CO}){ }_{10}-\right.$ $\left.\left(\mu-\mathrm{PPh}_{2}\right)\right]^{16}$ and $\mathrm{CO}^{17}$ were prepared by literature methods. The reactions were monitored by IR and NMR spectroscopies. Preparative TLC was carried out in air by using $c a 2$ $\mathrm{mm}$ thick glass backed silica plates $(20 \times 20 \mathrm{~cm})$ prepared from silica gel GF 254 Type, Fluka, $\mathrm{CH}_{2} \mathrm{Cl}_{2}$-hexane (1:3) as eluent, unless otherwise specified, and the compounds were extracted from silica with $\mathrm{CH}_{2} \mathrm{Cl}_{2}$. IR spectra were obtained on a Bomen $\mathrm{MB}$ series IR instrument scanning between 2200 and $1500 \mathrm{~cm}^{-1}$, using $\mathrm{CaF}_{2}$ cells. ${ }^{1} \mathrm{H}$, ${ }^{13} \mathrm{C}\left\{{ }^{1} \mathrm{H}\right\}$ and ${ }^{31} \mathrm{P}\left\{{ }^{1} \mathrm{H}\right\}$ NMR data were obtained on a Bruker AC 300/P instrument using deuterated solvents as lock and reference $\left[{ }^{1} \mathrm{H}\right.$ and ${ }^{13} \mathrm{C}, \mathrm{SiMe}_{4},{ }^{31} \mathrm{P}, 85 \% \mathrm{H}_{3} \mathrm{PO}_{4}$ (external)]. Microanalyses were performed on a Perkin Elmer 2401 Elemental Analysis instrument at the Chemistry Institute of UNICAMP. FAB Mass spectrum was obtained on a VG 7070E-HF mass spectrometer using nitrobenzyl alcohol as the matrix at the Chemistry Department the University of Minnesota.

Preparation of $\left[\operatorname{Ir}_{4}(\mathrm{CO})_{8}\left(\mathrm{CH}_{3}\right)\left(\mu_{4}-\eta^{3}-P h_{2} P C C P h\right)\left(\mu-P P h_{2}\right)\right]$, 2

To an orange solution of $\mathbf{1}(100 \mathrm{mg}, 0.08 \mathrm{mmol})$ in THF (30 mL) cooled to $0^{\circ} \mathrm{C}$ were added sequentially BuLi (50.0 $\mu \mathrm{L}, 0.08 \mathrm{mmol}), \mathrm{Ph}_{2} \mathrm{PC} \equiv \mathrm{CPh}(23.2 \mathrm{mg}, 0.08 \mathrm{mmol})$ and $\mathrm{CH}_{3} \mathrm{I}(5.0 \mu \mathrm{L}, 0.08 \mathrm{mmol})$. The resulting mixture was allowed to warm slowly to room temperature and left stirring for $30 \mathrm{~min}$. The solvent was evaporated and the residue dissolved in $\mathrm{CH}_{2} \mathrm{Cl}_{2}$; TLC of the solution gave red compound 2 (34.0 mg, 34\%; Rf $=0.65)$, yellow $\left[\operatorname{Ir}_{4}(\mathrm{CO})_{9}\left(\mu_{3}-\eta^{3}-\mathrm{Ph}_{2} \mathrm{PC}(\mathrm{H}) \mathrm{CPh}\right)\left(\mu-\mathrm{PPh}_{2}\right)\right](27.0 \mathrm{mg}, 23 \%$; $\mathrm{Rf}=0.60)$ and orange $\left[(\mu-\mathrm{H}) \operatorname{Ir} 4(\mathrm{CO}){ }_{9}\left(\mathrm{Ph}_{2} \mathrm{PC} \equiv \mathrm{CPh}\right)-\right.$ $\left.\left(\mu-\mathrm{PPh}_{2}\right)\right]$ (36.0 mg, 30\%; $\left.\mathrm{Rf}=0.55\right)$. Compound 2 was crystallised from $\mathrm{CH}_{2} \mathrm{Cl}_{2}$-hexane $(1: 3)$ at $15^{\circ} \mathrm{C}$. Anal. Calc for $\mathrm{C}_{41} \mathrm{H}_{28} \mathrm{O}_{8} \mathrm{P}_{2} \mathrm{Ir}_{4} 2$ 2: C, 33.3; H $1.9 \%$. Found: C, 33.4; H, $1.7 \%$. IR (hexane, $\mathrm{cm}^{-1}$ ) vCO $2070 \mathrm{~m}, 2066 \mathrm{~s}, 2046 \mathrm{~s}, 2030 \mathrm{~m}$, $2012 \mathrm{~m}$.

\section{Reaction of $\left[\mathrm{Ir}_{4}(\mathrm{CO})_{8}\left(\mathrm{CH}_{3}\right)\left(\mu_{4}-\eta^{3}-P h_{2} P C C P h\right)\left(\mu-P P h_{2}\right)\right], 2$} with $\mathrm{CO}$

CO was bubbled through a solution of $2(40.0 \mathrm{mg}, 0.028$ $\mathrm{mmol})$ in $\mathrm{CH}_{2} \mathrm{Cl}_{2}(20 \mathrm{~mL})$ in a Schlenk tube at $0{ }^{\circ} \mathrm{C}$ for 20 min, after which time the dark red solution turned yellow with formation of 4. IR (hexane, $\mathrm{cm}^{-1}$ ) 4: vCO 2062w, 2042s, 2032s, 2002m, 1987m, 1851vw. When this yellow solution was stirred under Ar at $25{ }^{\circ} \mathrm{C}$ for $20 \mathrm{~min}, 2$ was obtained quantitatively. Heating the yellow $\mathrm{CH}_{2} \mathrm{Cl}_{2}$ solution of 4 at $40^{\circ} \mathrm{C}$ under $\mathrm{CO}$ for $7 \mathrm{~h}$ resulted in an orange solution. The solvent was evaporated under reduced pressure, the residue dissolved in $\mathrm{CH}_{2} \mathrm{Cl}_{2}$ and separated by TLC to give unreacted $2(7.6 \mathrm{mg}, 19 \% ; \mathrm{Rf}=0.65)$ and 
$\left[\mathrm{Ir}_{4}(\mathrm{CO})_{8}\left\{\mathrm{C}(\mathrm{O}) \mathrm{CH}_{3}\right\}\left(\mu_{4}-\eta^{3}-\mathrm{Ph}_{2} \mathrm{PCCPh}\right)\left(\mu-\mathrm{PPh}_{2}\right)\right], \quad 5$ (32.0 mg, 80\%; Rf =0.40), which was crystallised from $\mathrm{CH}_{2} \mathrm{Cl}_{2}$-hexane $(1: 3)$ at $15{ }^{\circ} \mathrm{C}$. Anal. Calc. for $\mathrm{C}_{42} \mathrm{H}_{28} \mathrm{O}_{9} \mathrm{P}_{2} \mathrm{Ir}_{4}: \mathrm{C}, 33.4 ; \mathrm{H} 1.8 \%$. Found: C, 33.4; H, $1.7 \%$. IR (hexane, $\mathrm{cm}^{-1}$ ) v $v_{\mathrm{CO}} 2074 \mathrm{~m}, 2062 \mathrm{~m}, 2026 \mathrm{~s}, 1995 \mathrm{wbr}$, 1960w, 1695w.

\section{Preparation of the NMR sample of $\mathbf{4}$ for VT experiments}

A solution of $2(20.0 \mathrm{mg}, 0.014 \mathrm{mmol})$ in $\mathrm{CD}_{2} \mathrm{Cl}_{2}(1.5$ $\mathrm{mL}$ ) was added to a $5 \mathrm{~mm}$ NMR tube. $\mathrm{CO}$ was bubbled through the solution for $15 \mathrm{~min}$ at $0{ }^{\circ} \mathrm{C}$. The NMR tube was sealed under a positive pressure of $\mathrm{CO}$.

$C O$ de-insertion reaction of the cluster $\left[\mathrm{Ir}_{4}(\mathrm{CO})_{8}\left\{\mathrm{C}(\mathrm{O}) \mathrm{CH}_{3}\right\}\left(\mu_{4}-\eta^{3}-\mathrm{Ph} h_{2} \mathrm{PCCPh}\right)\left(\mu-\mathrm{PPh}_{2}\right)\right], \mathbf{5}$

Compound 5 (20.0 mg, $0.014 \mathrm{mmol}$ ) was heated in THF $\left(20 \mathrm{~mL}\right.$ ) under $\mathrm{Ar}$ at $60{ }^{\circ} \mathrm{C}$ for $4 \mathrm{~h}$, after which time the solvent was evaporated and the residue dissolved in $\mathrm{CH}_{2} \mathrm{Cl}_{2}$. TLC of the red solution gave compound 2 quantitatively.

Reaction of $\left[\operatorname{Ir}_{4}(\mathrm{CO})_{8}\left(\mathrm{CH}_{3}\right)\left(\mu_{4}-\eta^{3}-P h_{2} P C C P h\right)\left(\mu-P P h_{2}\right)\right]$, 2, with $\mathrm{PPh}_{3}$

A solution of $2(40.0 \mathrm{mg}, 0.028 \mathrm{mmol})$ and $\mathrm{PPh}_{3}(7.1$ $\mathrm{mg}, 0.028 \mathrm{mmol})$ in THF $(30 \mathrm{~mL})$ was stirred for $2.5 \mathrm{~h}$ at $28{ }^{\circ} \mathrm{C}$. The solvent was evaporated, the green residue dissolved in $\mathrm{CH}_{2} \mathrm{Cl}_{2}$ and separated by TLC to give an olive green compound $6(20.0 \mathrm{mg}, 35 \%$; $\mathrm{Rf}=0.65)$; heavy decomposition was noted on the base line. Microcrystals were obtained from $\mathrm{CH}_{2} \mathrm{Cl}_{2} /$ hexane at $4{ }^{\circ} \mathrm{C}$. Anal. Calc. for $\mathrm{C}_{58} \mathrm{H}_{43} \mathrm{O}_{8} \mathrm{P}_{3} \mathrm{Ir}_{4}: \mathrm{C}, 40.4 ; \mathrm{H} 2.5 \%$. Found: C, 40,2; H, $2.6 \%$. IR (hexane, $\mathrm{cm}^{-1}$ ): $v_{\mathrm{CO}}$ 2052s, 2036w, 2016m, 1993s, 1966m, 1944wbr.

\section{Reaction of $\left[\mathrm{Ir}_{4}(\mathrm{CO})_{8}\left(\mathrm{CH}_{3}\right)\left(\mu_{4}-\eta^{3}-P h_{2} P C C P h\right)\left(\mu-P P h_{2}\right)\right]$,} 2, with $\mathrm{P}(\mathrm{OMe})_{3}$

Addition of $\mathrm{P}(\mathrm{OMe})_{3}(3.2 \mu \mathrm{L}, 0.028 \mathrm{mmol})$ to a solution of $2(40.0 \mathrm{mg}, 0.028 \mathrm{mmol})$ in THF ( $30 \mathrm{~mL})$ resulted in an immediate colour change from red to yellow and then dark green. After $10 \mathrm{~min}$ stirring at $28{ }^{\circ} \mathrm{C}$, the solvent was evaporated and the residue dissolved in $\mathrm{CH}_{2} \mathrm{Cl}_{2}$; TLC of the solution gave an olive green compound 7 (10 mg, 25\%; $\mathrm{Rf}=0.60$ ); heavy decomposition was noted on the base line. IR (hexane, $\mathrm{cm}^{-1}$ ): v CO 2054s, 2016s, 1993w, 1967m, $1953 \mathrm{vw}, 1944 \mathrm{vw}$.

\section{Crystal structure characterisation}

Diffraction data collections for $\mathbf{2}$ and $\mathbf{5}$ were carried out on an Enraf-Nonius CAD4. Crystal data for 2: $\mathrm{C}_{41} \mathrm{H}_{28} \mathrm{Ir}_{4} \mathrm{O}_{8} \mathrm{P}_{2}, M=1475.4$, triclinic, space group P-1, $a=$ 11.452(2), $\mathrm{b}=17.386(7), \mathrm{c}=11.231(5) \AA, \alpha=94.38(5)$, $\beta=113.59(2), \gamma=89.50(2)^{\circ}, U=2043 \AA^{3}, Z=2, D_{\mathrm{c}}=2.40$

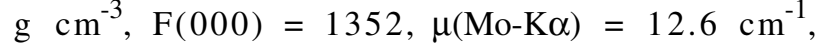
$2.5<\theta<25^{\circ}$, final $\mathrm{R}$ value $0.043, R_{\mathrm{W}}=0.049$ for 5682 out of 7798 independent reflections [I $>2 \sigma(\mathrm{I})]$. Crystal data for 5: $\mathrm{C}_{42} \mathrm{H}_{28} \mathrm{Ir} 4 \mathrm{O}_{9} \mathrm{P}_{2}, M=1503.4$, triclinic, space group $\mathrm{P}-1$, $a=11.426(4), \mathrm{b}=17.537(6), \mathrm{c}=11.335(5) \AA, \alpha=93.96(3)$, $\beta=113.24(3), \gamma=88.86(3)^{\circ}, U=2082 \AA^{3}, Z=2, D_{\mathrm{c}}=2.40$ $\mathrm{g} \mathrm{cm}^{-3}, \mathrm{~F}(000)=1380, \mu(\mathrm{Mo}-\mathrm{K} \alpha)=12.4 \mathrm{~cm}^{-1}, 2<\theta<25^{\circ}$, final $R$ value $0.078, R_{\mathrm{W}}=0.075$ for 3983 out of 7696 independent reflections $[\mathrm{I}>2 \sigma(\mathrm{I})]$. SHELX $86^{18}$ and SHELXL $76^{19}$ were used for data treatment and refinement based on $\mathrm{F}^{2}$. Absorption correction was applied by the Walker and Stuart method ${ }^{20}$ (correction ranges $0.61-1.00$ for 2 and $0.55-1.00$ for 5, respectively). All non-H atoms were allowed to vibrate anisotropically. $\mathrm{H}$ atoms were added in calculated positions ( $\mathrm{C}-\mathrm{H} 0.93 \AA$ ) and refined "riding" on the corresponding $\mathrm{C}$ atoms. Additional details of measurements and refinement, atomic coordinates, thermal parameters and a full list of bond lengths and angles have been deposited at the Cambridge Crystallographic Data Centre. SCHAKAL92 ${ }^{21}$ was used for the graphical representation of the results.

\section{Results and Discussion}

Treatment of $\left[(\mu-\mathrm{H}) \operatorname{Ir}_{4}(\mathrm{CO})_{10}\left(\mu-\mathrm{PPh}_{2}\right)\right], \mathbf{1}$, with $\mathrm{BuLi}$ at $0{ }^{\circ} \mathrm{C}$ in THF affords $\left[\mathrm{Ir}_{4}(\mathrm{CO})_{10}\left(\mu-\mathrm{PPh}_{2}\right)\right]^{-}$that reacts in situ with $\mathrm{Ph}_{2} \mathrm{PCCPh}$ and MeI to afford the novel compound $\left[\mathrm{Ir} 4(\mathrm{CO}){ }_{8}\left(\mathrm{CH}_{3}\right)\left(\mu \mu_{4}-\eta^{3}-\mathrm{Ph}_{2} \mathrm{PCCPh}\right)\left(\mu-\mathrm{PPh}_{2}\right)\right], \mathbf{2}$, in $34 \%$ yield, after purification by TLC. The known species $\left[\mathrm{Ir}_{4}(\mathrm{CO})_{9}\left(\mu_{3}-\eta^{3}-\mathrm{Ph}_{2} \mathrm{PC}(\mathrm{H}) \mathrm{CPh}\right)\left(\mu-\mathrm{PPh}_{2}\right)\right] \quad(23 \%)$ and $\left[(\mu-\mathrm{H}) \mathrm{Ir}_{4}(\mathrm{CO}) 9\left(\mathrm{Ph}_{2} \mathrm{PC} \equiv \mathrm{CPh}\right)\left(\mu-\mathrm{PPh}_{2}\right)\right](30 \%)$ were also isolated, probably due to the presence of moisture in the reaction mixture, and identified by IR and NMR spectroscopies $^{8}$. Compound $\mathbf{2}$ was characterised by a combination of IR spectroscopy, satisfactory microanalysis (see Experimental), FAB MS and ${ }^{1} \mathrm{H},{ }^{13} \mathrm{C}\left\{{ }^{1} \mathrm{H}\right\}$ and ${ }^{31} \mathrm{P}\left\{{ }^{1} \mathrm{H}\right\}$ NMR spectroscopies (see Table 1 ). The FAB mass spectrum of 2 contains peaks at $1482\left(\mathrm{M}^{+}\right)=\mathrm{M}^{\prime} ; 1454$ $(\mathrm{M}-\mathrm{CO})^{+} ; 1383\left(\mathrm{M}^{\prime}-3 \mathrm{CO}-\mathrm{CH}_{3}\right)^{+} ; 1243\left(\mathrm{M}^{\prime}-8 \mathrm{CO}-\mathrm{CH}_{3}\right)^{+}$ and $957\left(\mathrm{M}^{\prime}-8 \mathrm{CO}-\mathrm{CH}_{3}-\mathrm{Ph}_{2} \mathrm{PCCPh}\right)^{+}$. Only terminal $v_{\mathrm{CO}}$ bands are observed in the IR spectrum of 2 . The ${ }^{1} \mathrm{H}-\mathrm{NMR}$ at $22{ }^{\circ} \mathrm{C}$ contains signals assigned to phenyl groups and to a cluster bound methyl group at $\delta 1.28$ (s). This resonance is in the chemical shift range characteristic of methyl ligand bound to neutral clusters in which no M...C...H interaction is present ${ }^{11}\left(\right.$ e.g. $\left[\left(\mathrm{CH}_{3}\right) \mathrm{Os}_{3}(\mathrm{CO})_{10}(\mu-\mathrm{I})\right], \delta$ 1.34) and neutral $\operatorname{Ir}(\mathrm{I})$ mononuclear species (e.g. trans-[MeIr(CO) $\left.\mathrm{L}_{2}\right], \quad \mathrm{L}=\mathrm{P}\left(\mathrm{p}-\mathrm{C}_{6} \mathrm{H}_{4} \mathrm{OMe}\right)_{3}, \quad \delta 1.29$, $\left.\mathrm{PPh}_{2} \mathrm{Me}, \delta 1.80\right)^{22}$. The ${ }^{13} \mathrm{C}\left\{{ }^{1} \mathrm{H}\right\}$ NMR spectrum at $22{ }^{\circ} \mathrm{C}$ of a sample enriched with ${ }^{13} \mathrm{CH}_{3}$ exhibits a singlet at $\delta$ -24.09 , indicating that this group is not bound to the same Ir atom as the $\mathrm{PPh}_{2}$ and $\mathrm{Ph}_{2} \mathrm{PCCPh}$ ligands, as is observed 
Table 1. ${ }^{1} \mathrm{H},{ }^{13} \mathrm{C}\left\{{ }^{1} \mathrm{H}\right\}$ and ${ }^{31} \mathrm{P}\left\{{ }^{1} \mathrm{H}\right\}$ NMR data for $\left[\operatorname{Ir}_{4}(\mathrm{CO}) 8\left(\mathrm{CH}_{3}\right)\left(\mu_{4}-\eta^{3}-\mathrm{Ph}_{2} \mathrm{PCCPh}\right)\left(\mu-\mathrm{PPh}_{2}\right)\right], 2$, $\left[\mathrm{HIr}_{4}(\mathrm{CO}) 9\left(\mu \mu_{4}-\eta^{3}-\mathrm{Ph} 2 \mathrm{PCCPh}\right)(\mu-\mathrm{PPh} 2)\right], 3$, "[Ir $\left.4(\mathrm{CO})_{9}\left(\mathrm{CH}_{3}\right)\left(\mu_{4}-\eta^{3}-\mathrm{Ph}_{2} \mathrm{PCCPh}\right)\left(\mu-\mathrm{PPh}_{2}\right)\right] " \mathbf{4 A}$ and $\mathbf{4 B},\left[\operatorname{Ir}_{4}(\mathrm{CO})_{8}\left\{\mathrm{C}(\mathrm{O}) \mathrm{CH}_{3}\right\}\left(\mu_{4}-\eta^{3}-\mathrm{Ph}_{2} \mathrm{PCCPh}\right)\left(\mu-\mathrm{PPh}_{2}\right)\right], \mathbf{5}$, and $\left[\operatorname{Ir}_{4}(\mathrm{CO})_{7}\left(\mathrm{PPh}_{3}\right)-\left(\mathrm{CH}_{3}\right)\left(\mu_{4}-\eta^{3}-\right.\right.$ $\left.\left.\mathrm{Ph}_{2} \mathrm{PCCPh}\right)\left(\mu-\mathrm{PPh}_{2}\right)\right]$ 6A and $\mathbf{6 B}$.

\begin{tabular}{|c|c|c|c|c|c|}
\hline \multirow[t]{2}{*}{ Compound } & \multirow{2}{*}{${ }^{1} \mathrm{H}-\mathrm{NMR}(\delta), \mathrm{J}(\mathrm{Hz})$} & \multirow[t]{2}{*}{${ }^{13} \mathrm{C}\left\{{ }^{1} \mathrm{H}\right\} \operatorname{NMR}(\delta) \mathrm{J}(\mathrm{Hz})$} & \multicolumn{3}{|c|}{${ }^{31} \mathrm{P}\left\{{ }^{1} \mathrm{H}\right\} \mathrm{NMR}(\delta), \mathrm{J}(\mathrm{Hz})$} \\
\hline & & & $\mathrm{Ph}_{2} \mathrm{PCCPh}(\mathrm{P} 1)$ & $\mathrm{PPh}_{2}(\mathrm{P} 2)$ & $\mathrm{PPh}_{3}(\mathrm{P} 3)$ \\
\hline $2^{\mathrm{a}}$ & $\begin{array}{c}1.28\left(\mathrm{~s}, 3 \mathrm{H}, \mathrm{CH}_{3}\right) \\
6.60-8.40(\mathrm{~m}, 25 \\
\mathrm{H}, \mathrm{Ph})\end{array}$ & $-24.09\left(\mathrm{~s}, \mathrm{CH}_{3}\right)$ & $-47.2(\mathrm{~d}), \mathrm{J}_{\mathrm{P} 1-\mathrm{P} 2}=193$ & $73.8(d)$ & \\
\hline $3^{20, b}$ & $\begin{array}{c}-11.2(\mathrm{~d}, \mathrm{~d}, \text { hydride }) \\
\mathrm{J}_{\mathrm{P} 1-\mathrm{H}}=90 ; \mathrm{J}_{\mathrm{P} 2-\mathrm{H}}=23 \\
6.6-7.6(\mathrm{~m}, 25 \mathrm{H}, \mathrm{Ph})\end{array}$ & & $-2.3(\mathrm{~d}) \mathrm{J}_{\mathrm{P} 1-\mathrm{P} 2}=42.2$ & $29.8(\mathrm{~d})$ & \\
\hline $\begin{array}{l}\mathbf{4} \mathbf{A}^{\mathrm{c}} \\
\text { and } \\
\mathbf{4 B}\end{array}$ & $\begin{array}{c}0.71\left(\mathrm{~d}, \mathrm{CH}_{3}\right) ; \mathrm{J}_{\mathrm{H}-\mathrm{C}}= \\
120.8 ; \\
5.34-8.16(\mathrm{~m}, \mathrm{Ph})\end{array}$ & $\begin{array}{c}-36.7\left(\mathrm{~s}, \mathrm{CH}_{3}\right) \\
-26.8\left(\mathrm{~d}, \mathrm{CH}_{3}\right) ; \mathrm{J}_{\mathrm{C}-\mathrm{P} 2}=13\end{array}$ & $\begin{aligned}-13.2(\mathrm{~d}) \quad \mathrm{JP1-P} 2 & =18 \\
0.1(\mathrm{~d}) \quad \mathrm{J}_{\mathrm{P} 1-\mathrm{P} 2} & =24\end{aligned}$ & $\begin{array}{c}136.7(d) \\
127.9(\mathrm{dd}) \mathrm{JP}_{-\mathrm{C}}=13\end{array}$ & \\
\hline $5^{\mathrm{a}}$ & $\begin{array}{c}2.43 \\
\left(\mathrm{~s}, 3 \mathrm{H}, \mathrm{C}(\mathrm{O}) \mathrm{CH}_{3}\right) \\
6.60-8.30 \\
(\mathrm{~m}, 25 \mathrm{H}, \mathrm{Ph})\end{array}$ & $48.43\left(\mathrm{~s},(\mathrm{O}) \mathrm{CH}_{3}\right)$ & -50.7 (d) $\quad \mathrm{J}_{\mathrm{P} 1-\mathrm{P} 2}=194$ & $79.1(\mathrm{~d})$ & \\
\hline $\begin{array}{l}\mathbf{6} \mathbf{A}^{\mathrm{b}} \\
\text { and } \\
\mathbf{6 B}\end{array}$ & $\begin{array}{l}0.28,0(\mathrm{~s}) \text { and } 0.43 \\
(\mathrm{~s})\left(1: 1 ; \mathrm{CH}_{3}\right) ; 6.60- \\
8.10(\mathrm{~m}, \mathrm{Ph})\end{array}$ & & $\begin{array}{c}-52.2(\mathrm{~d}, \mathrm{~d}) \mathrm{J}_{\mathrm{P} 1-\mathrm{P} 2}=228 \\
\mathrm{~J}_{\mathrm{P} 1-\mathrm{P} 3}=13 \\
-41.9(\mathrm{~d}, \mathrm{~d}) \mathrm{J}_{\mathrm{P} 1-\mathrm{P} 2}=189 \\
\mathrm{~J}_{\mathrm{P} 1-\mathrm{P} 3}=10\end{array}$ & $\begin{array}{c}77.3(\mathrm{~d}, \mathrm{~d}) \mathrm{J}_{\mathrm{P} 2-\mathrm{P} 3}=13 \\
65.9(\mathrm{~d})\end{array}$ & $\begin{array}{c}13.7(\mathrm{~d}, \mathrm{~d}) \\
6.1(\mathrm{~d})\end{array}$ \\
\hline
\end{tabular}

a $\mathrm{CD}_{2} \mathrm{Cl}_{2}, 298 \mathrm{~K} ; \mathrm{b} \mathrm{CDCl}_{3}, 223 \mathrm{~K} ; \mathrm{CD}_{2} \mathrm{Cl}_{2}, 190 \mathrm{~K} ; \mathrm{d} \mathrm{CDCl}_{3}, 298 \mathrm{~K}$.

in the hydride compound $\left[\mathrm{HIr}_{4}(\mathrm{CO}) 9\left(\mu_{4}-\eta^{3}-\mathrm{Ph}_{2} \mathrm{PCCPh}\right)\left(\mu-\mathrm{PPh}_{2}\right)\right], 3$. Analysis of the carbonyl region of this spectrum was not possible because the cluster was not enriched with ${ }^{13} \mathrm{CO}$. Discussion of the ${ }^{31} \mathrm{P}\left\{{ }^{1} \mathrm{H}\right\}$ NMR spectrum is deferred until the solid state structure is presented.

\section{Molecular structure of $\mathbf{2}$}

The molecular structure of $\mathbf{2}$ in the solid state is shown in Fig. 1 together with the labeling scheme. Relevant structural parameters are shown in Table 2. It exhibits a flat butterfly arrangement of metal atoms, all of which interact with the 6 electron donor $\mu_{4}-\eta^{3}-\mathrm{Ph}_{2} \mathrm{PCCPh}$ ligand, via two $\sigma$-interactions [ $\operatorname{Ir}(1)-\mathrm{C}(22)$ 2.09(1) and $\operatorname{Ir}(4)-\mathrm{C}(23)$ 2.07(1) $\AA$ ], one $\pi$-interaction $[\operatorname{Ir}(2)-\mathrm{C}(22) 2.33(1)$ and $\operatorname{Ir}(2)-\mathrm{C}(23)$ 2.30(1) $\AA$ ] and one two-electron P-Ir bond $\{\operatorname{Ir}(3)-\mathrm{P}(1)$ 2.29(3) Å]. Metal-metal bond distances range from 2.65(2) to 2.91(1) $\AA$, the longest bond being "edge spanned" by the diphenylphosphido ligand. The methyl group is bonded terminally to a wingtip Ir atom [C(9)-Ir(4) 2.14(0.01) $\AA$ ], contributing with one-electron to the polyhedron. Eight $\mathrm{CO}$ ligands are terminally bound, two to each iridium atom, four in radial and the remaining four in axial positions with respect to the metal frame. This cluster contains 62 valence electrons, as predicted by Wade rules ${ }^{23}$, but so far it is the first $\mathrm{Ir}_{4}$ cluster that does not obey the 18 electron rule at each metal centre: $\operatorname{Ir}(1)$ and $\operatorname{Ir}(4)$ have formally 17 and $\operatorname{Ir}(2)$

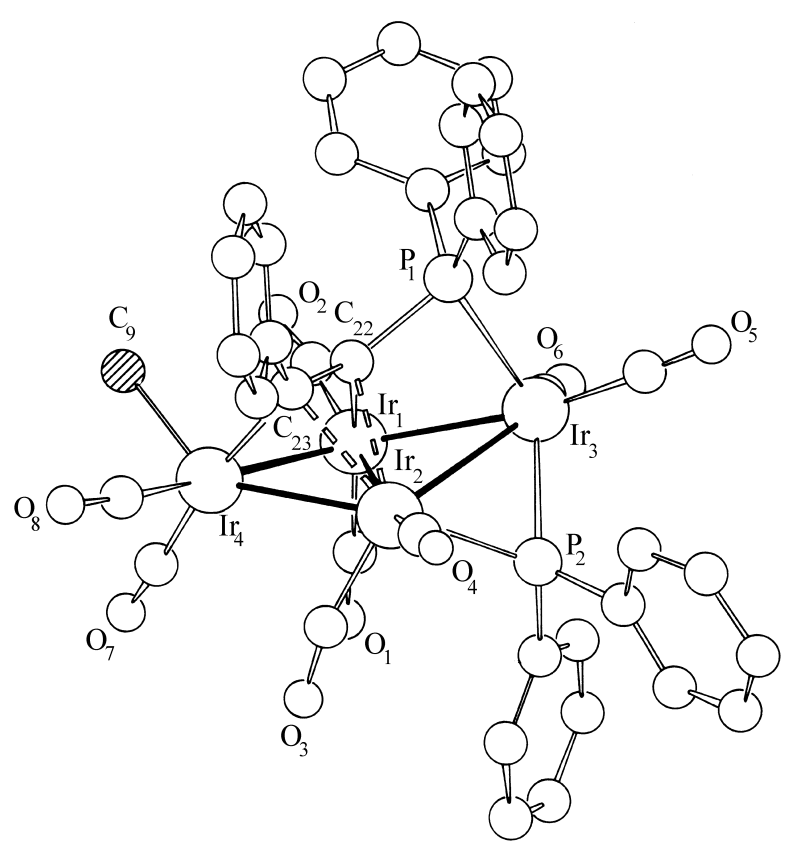

Figure 1. Molecular structure of $\left[\operatorname{Ir}_{4}(\mathrm{CO})_{8}\left(\mathrm{CH}_{3}\right)\left(\mu_{4}-\eta^{3}-\mathrm{Ph}_{2} \mathrm{PCCPh}\right)\right.$ $\left.\left(\mu-\mathrm{PPh}_{2}\right)\right], 2$.

and $\operatorname{Ir}(3), 19$ valence electrons, which explains the difficulty in proposing a structure based on spectroscopic data. The only two CO ligands that deviate from linearity $[\operatorname{Ir}(2)-$ $\left.\mathrm{C}(3)-\mathrm{O}(3) 167.8(1.2)^{\circ}\right]$ and $\left.\operatorname{Ir}(3)-\mathrm{C}(6)-\mathrm{O}(6) 169.2(1.3)^{\circ}\right]$ interact with the electron poor centres $\operatorname{Ir}(4)$ and $\operatorname{Ir}(1)$, re- 
Table 2. Relevant structural parameters for $\left[\operatorname{Ir}_{4}(\mathrm{CO})_{8}\left(\mathrm{CH}_{3}\right)\left(\mu_{4}-\eta^{3}-\right.\right.$ $\left.\left.\mathrm{Ph}_{2} \mathrm{PCCPh}\right)\left(\mu-\mathrm{PPh}_{2}\right)\right], 2$ and $\left[\mathrm{Ir}_{4}(\mathrm{CO})_{8}\left\{\mathrm{C}(\mathrm{O}) \mathrm{CH}_{3}\right\}\left(\mu_{4}-\eta^{3}-\mathrm{Ph}_{2} \mathrm{PCCPh}\right)(\mu-\right.$ $\left.\left.\mathrm{PPh}_{2}\right)\right], 5$.

\begin{tabular}{|c|c|c|}
\hline & 2 & 5 \\
\hline $\operatorname{Ir}(1)-\operatorname{Ir}(2)$ & $2.652(1)$ & $2.656(2)$ \\
\hline $\operatorname{Ir}(1)-\operatorname{Ir}(3)$ & $2.826(1)$ & $2.819(2)$ \\
\hline $\operatorname{Ir}(1)-\operatorname{Ir}(4)$ & $2.690(1)$ & $2.685(2)$ \\
\hline $\operatorname{Ir}(2)-\operatorname{Ir}(3)$ & $2.913(1)$ & $2.912(2)$ \\
\hline $\operatorname{Ir}(1)-C(22)$ & $2.09(1)$ & $2.12(4)$ \\
\hline $\operatorname{Ir}(4)-C(23)$ & $2.07(1)$ & $2.03(4)$ \\
\hline $\operatorname{Ir}(2)-C(22)$ & $2.38(1)$ & $2.47(3)$ \\
\hline $\operatorname{Ir}(2)-C(23)$ & $2.30(1)$ & $2.33(3)$ \\
\hline$C(22)-C(23)$ & $1.36(2)$ & $1.40(4)$ \\
\hline $\operatorname{Ir}(3)-\mathrm{P}(1)$ & $2.296(3)$ & $2.307(8)$ \\
\hline $\operatorname{Ir}(4)-C(9)$ & $2.14(1)$ & $2.00(4)$ \\
\hline $\mathrm{C}(9)-\mathrm{O}(9)$ & & $1.20(6)$ \\
\hline $\mathrm{C}(9)-\mathrm{C}(9 \mathrm{M})$ & & $1.54(9)$ \\
\hline $\operatorname{Ir}(1)-C(1)$ & $1.93(1)$ & $1.90(5)$ \\
\hline $\operatorname{Ir}(1)-C(2)$ & $1.85(1)$ & $1.71(5)$ \\
\hline $\operatorname{Ir}(2)-C(3)$ & $1.91(1)$ & $1.94(5)$ \\
\hline $\operatorname{Ir}(2)-C(4)$ & $1.92(1)$ & $1.91(3)$ \\
\hline $\operatorname{Ir}(3)-C(5)$ & $1.87(1)$ & $1.98(4)$ \\
\hline $\operatorname{Ir}(3)-C(6)$ & 1.91(1) & $1.87(3)$ \\
\hline $\operatorname{Ir}(4)-C(7)$ & $1.92(1)$ & $1.92(5)$ \\
\hline $\operatorname{Ir}(4)-C(8)$ & $1.87(1)$ & $1.85(3)$ \\
\hline $\operatorname{Ir}(1)-\mathrm{C}(1)-\mathrm{O}(1)$ & $175(1)$ & $172(3)$ \\
\hline $\operatorname{Ir}(1)-\mathrm{C}(2)-\mathrm{O}(2)$ & $174(1)$ & $168(4)$ \\
\hline $\operatorname{Ir}(2)-\mathrm{C}(3)-\mathrm{O}(3)$ & $167(1)$ & $164(4)$ \\
\hline $\operatorname{Ir}(2)-\mathrm{C}(4)-\mathrm{O}(4)$ & $178(1)$ & $177(4)$ \\
\hline $\operatorname{Ir}(3)-\mathrm{C}(5)-\mathrm{O}(5)$ & $177(1)$ & $172(3)$ \\
\hline $\operatorname{Ir}(3)-\mathrm{C}(6)-\mathrm{O}(6)$ & $169(1)$ & $171(4)$ \\
\hline $\operatorname{Ir}(4)-C(7)-O(7)$ & $177(1)$ & $169(3)$ \\
\hline $\operatorname{Ir}(4)-\mathrm{C}(8)-\mathrm{O}(8)$ & $176(1)$ & $176(3)$ \\
\hline $\operatorname{Ir}(2)-\mathrm{P}(2)-\operatorname{Ir}(3)$ & 78.1(1) & $77.9(3)$ \\
\hline $\mathrm{P}(1)-\operatorname{Ir}(3)-\mathrm{P}(2)$ & $135.6(1)$ & $135.8(3)$ \\
\hline$\underline{\operatorname{Ir}(4)-C(9)-C(9 M)}$ & & $118(4)$ \\
\hline
\end{tabular}

spectively, thus helping to redistribute the electron density in the metal frame. Similar Ir4 butterfly systems have been described previously, for example hydride $\mathbf{3}^{9}$, $\left[\mathrm{Ir}_{4}(\mathrm{CO})_{8}\left(\eta^{1}-\mathrm{Ph}\right)\left(\mu_{3}-\eta^{3}-\mathrm{PhPC}(\mathrm{H}) \mathrm{CPh}\right)\left(\mu-\mathrm{PPh}_{2}\right)\right]^{12}$ and $\left[\operatorname{Ir}_{4}(\mathrm{CO})_{8}\left(\mu_{4}-\eta^{3}-\mathrm{Ph}_{2} \mathrm{PC}(\mathrm{H}) \mathrm{C}(\mathrm{Ph}) \mathrm{PCBu}^{t}\right)\left(\mu-\mathrm{PPh}_{2}\right)\right]^{24}$.

The structure of compound $\mathbf{2}$ is markedly different from that of the hydrido cluster $\left[\mathrm{HIr}_{4}(\mathrm{CO}) 9\left(\mu_{4}-\eta^{3}-\mathrm{Ph}_{2} \mathrm{PCCPh}\right)-\right.$ $\left.\left(\mu-\mathrm{PPh}_{2}\right)\right], 3$ (see Fig. 2$)^{9}$, and a comparison of structural and spectroscopic parameters for these two clusters is instructive. Compound $\mathbf{3}$ bears one additional $\mathrm{CO}$ ligand on

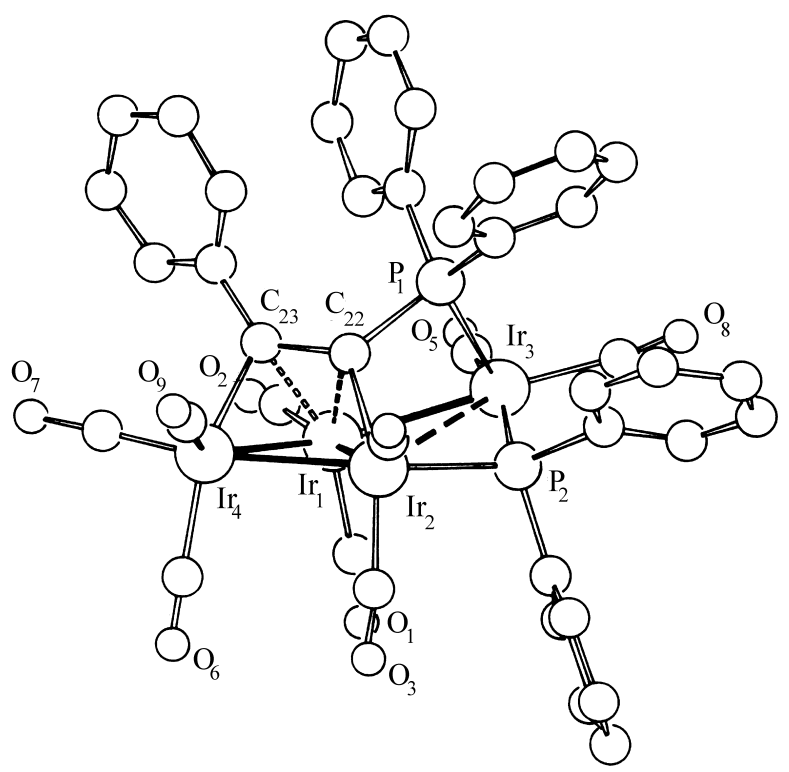

Figure 2. Molecular structure of $\left[\mathrm{HIr}_{4}(\mathrm{CO}) 9\left(\mu_{4}-\eta^{3}-\mathrm{Ph}{ }_{2} \mathrm{PCCPh}\right)(\mu-\right.$ $\left.\left.\mathrm{PPh}_{2}\right)\right], 3$.

$\operatorname{Ir}(4)$, in place of the methyl group on $\mathbf{2}$, and a hydride ligand bonded to $\operatorname{Ir}(3)$, that is, to the opposite wing of the butterfly to where the methyl group is bound in $\mathbf{2}$. In both cases, the $\mathrm{Ph}_{2} \mathrm{PCCPh}$ ligand interacts with all four metal atoms, however, in cluster 3 , the acetylene moiety $\pi$-interacts with $\operatorname{Ir}(1)$ and $\sigma$-interacts with $\operatorname{Ir}(2)$ and $\operatorname{Ir}(4)$, i.e. the $\mathrm{C}$-C bond is parallel to the $\operatorname{Ir}(2)-\operatorname{Ir}(4)$ segment, whilst in $\mathbf{2}$ this bond is parallel to the $\operatorname{Ir}(1)-\operatorname{Ir}(4)$ bond. In both clusters the phosphido ligand bridges the $\operatorname{Ir}(2)-\operatorname{Ir}(3)$ segment, but only in the 62 butterfly methyl cluster $\mathbf{2}$ these two metal atoms interact formally. As a result of the additional CO ligand, in the 64 electron spiked triangular cluster $\mathbf{3}$, this distance is rather long $[\operatorname{Ir}(2)---\operatorname{Ir}(3) 3.686(2) \AA]$. Furthermore, the $\mathrm{PPh}_{2}$ ligand in 3 is pushed towards the $\operatorname{Ir}(1)-\operatorname{Ir}(2)-\operatorname{Ir}(3)$ plane, compared to the methyl cluster $\mathbf{2}$, possibly due to the presence of the additional hydride on $\operatorname{Ir}(3)$ and to the lengthening of the $\operatorname{Ir}(2)-\operatorname{Ir}(3)$ distance.

\section{Solution structure of $\mathbf{2}$}

The structural differences observed in $\mathbf{2}$ and $\mathbf{3}$ are reflected in the ${ }^{31} \mathrm{P}\left\{{ }^{1} \mathrm{H}\right\}$ NMR spectra of these compounds that have been extremely useful for rapid diagnosis of the structure of derivatives of this class of compounds ${ }^{24}$. Correlations between the $\mathrm{M}-\mathrm{PR}_{2}-\mathrm{M}$ angles and the ${ }^{31} \mathrm{P}$ chemical shifts in closely related phosphido containing compounds show that the larger this angle (and consequently the longer the $\mathrm{M}-\mathrm{M}$ vector), the lower the chemical shift frequency of the phosphido $\mathrm{P}^{25}$. As expected, the increase in the $\operatorname{Ir}(2)-\mathrm{P}(2)-\operatorname{Ir}(3)$ angle from 78.1(1) ${ }^{\circ}$ in $\mathbf{2}$ to $103.3(3)^{\circ}$ in $\mathbf{3}$ results in a rather drastic shift from $\delta 73.8$ to 29.8 , respectively. The $\mathrm{Ph}_{2} \mathrm{PCCPh}$ 
phosphorus (P1) appears at $\delta-47.2$ in $\mathbf{2}$ and at $\delta-2.3$ in $\mathbf{3}$, and the decrease in the $\mathrm{P}(1)-\operatorname{Ir}(3)-\mathrm{P}(2)$ angle from 135.6 $(0.1)^{\circ}$ in 2 to $85.4(0.1)^{\circ}$ in $\mathbf{3}$ results in a marked decrease in the observed JP1-P2 from 193 to $42 \mathrm{~Hz}$, respectively.

These rather dramatic structural differences are noteworthy, considering that the methyl cluster $\mathbf{2}$ and the hydride compound $\mathbf{3}$ are obtained from analogous synthetic routes, i.e. from the addition of the isolobal fragments $\mathrm{Me}^{+}$ and $\mathrm{H}^{+}$, respectively, to the same anionic precursor.

It has been shown that the metal atoms and the oxygen of the carbonyl ligands are potential sites for eletrophilic attack. It is clear, however, that the nature of the product may not reflect the actual site of attack of the electrophile, as cluster rearrangements may occur. Also, the different electronic and steric requirements of the two electrophiles may lead to the stabilisation of structures containing the $\mathrm{H}$ and $\mathrm{Me}$ in different positions (metal or oxygen). For example, low temperature ${ }^{1} \mathrm{H}-\mathrm{NMR}$ studies have evidenced that protonation (at $-60{ }^{\circ} \mathrm{C}$ ) of $\left[(\mu-\mathrm{H}) \mathrm{Ru}_{3}(\mu-\mathrm{CO})(\mathrm{CO})_{10}\right]^{-}$occurs at the oxygen atom of a bridging $\mathrm{CO}$ ligand to give $\left[(\mu-\mathrm{H}) \mathrm{Ru}_{3}(\mu-\mathrm{COH})(\mathrm{CO})_{10}\right]$, with a subsequent rearrangement $\left(>-30{ }^{\circ} \mathrm{C}\right)$ to the thermodynamically stable dihydride $\left[\mathrm{H}(\mu-\mathrm{H}) \mathrm{Ru}(\mathrm{CO})_{11}\right]$, via migration of the hydrogen to the metal frame $\mathrm{e}^{26,27}$. The methylation (at $25{ }^{\circ} \mathrm{C}$ ) of $\left[(\mu-\mathrm{H}) \mathrm{Ru} 3(\mu-\mathrm{CO})(\mathrm{CO})_{10}\right]^{-}$, however, gives the thermodynamically stable $\left[(\mu-\mathrm{H}) \mathrm{Ru}_{3}\left(\mu-\mathrm{COCH}_{3}\right)(\mathrm{CO})_{10}\right]^{28}$.

Assuming that formation of compounds $\mathbf{2}$ and $\mathbf{3}$ involves initial electrophilic attack of $\mathrm{Me}^{+}$and $\mathrm{H}^{+}$, respectively, at the oxygen of a carbonyl group of the anionic product from the reaction of $\left[\mathrm{Ir}_{4}(\mathrm{CO})_{10}\left(\mu-\mathrm{PPh}_{2}\right)\right]^{-}$ with $\mathrm{Ph}_{2} \mathrm{PC} \equiv \mathrm{CPh}$, the different positions occupied by the $\mathrm{Me}$ and $\mathrm{H}$ groups in the respective products, probably reflect: i) the relative ease of migration of these groups to the metal frame, i.e. the relative rates of $\mathrm{CO}$ de-insertion and also of $\mathrm{CO}$ dissociation; ii) the different steric and electronic requirements of the two groups. Steric effects probably play a minor role in the final position of the $\mathrm{H}$ and Me groups, considering that the ethyl cluster $\left[\mathrm{Ir}_{4}(\mathrm{CO})_{8}\left(\mathrm{CH}_{2} \mathrm{CH}_{3}\right)\left(\mu_{4}-\eta^{3}-\mathrm{Ph}_{2} \mathrm{PCCPh}\right)\left(\mu-\mathrm{PPh}_{2}\right)\right]$, analogous to 2 , and recently obtained from the reaction of the hydride compound $\mathbf{3}$ with ethylene, contains the ethyl group in the position occupied by the hydride ligand in the precursor $3^{29}$. With this argument in mind, the carbonylation reactions of the methyl and hydride clusters $\mathbf{2}$ and $\mathbf{3}$, respectively, were investigated.

\section{Reactions of $\mathbf{2}$ and $\mathbf{3}$ with $\mathrm{CO}$}

Compound 3 does not react with $\mathrm{CO}(>1 \mathrm{~atm}$, toluene, $\left.60{ }^{\circ} \mathrm{C}, 24 \mathrm{~h}\right)^{9}$. In contrast, compound 2 reacts with $\mathrm{CO}$ under mild conditions ( $1 \mathrm{~atm}, \mathrm{CH}_{2} \mathrm{Cl}_{2}$, room temperature, $20 \mathrm{~min}$ )

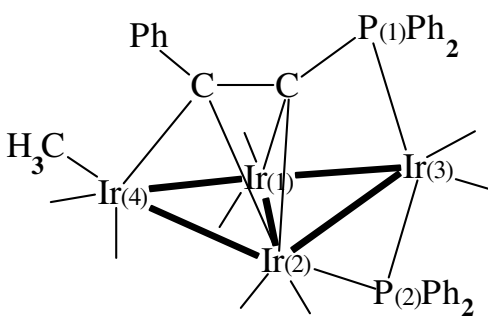

2
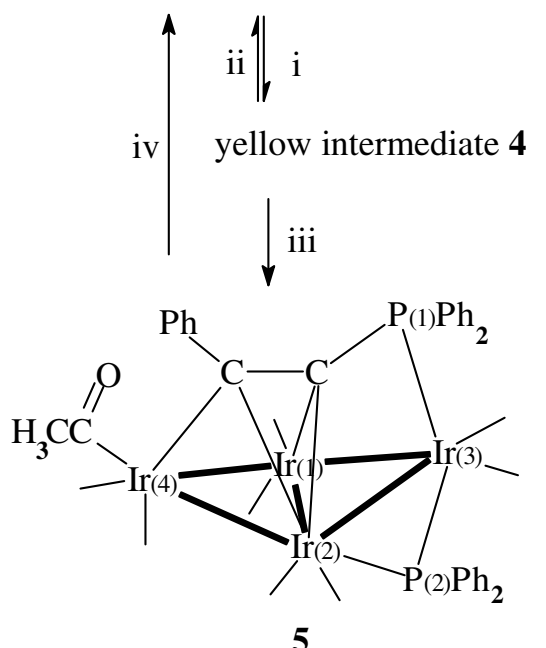

Scheme 1. Reaction of $\left[\mathrm{Ir}_{4}(\mathrm{CO})_{8}\left(\mathrm{CH}_{3}\right)\left(\mu_{4}-\eta^{3}-\mathrm{Ph}_{2} \mathrm{PCCPh}\right)\left(\mu-\mathrm{PPh}_{2}\right)\right], 2$, with CO. Reagents and conditions: (i) CO, $1 \mathrm{~atm}$, THF, RT, $20 \mathrm{~min}$; (ii) $\mathrm{Ar}$, THF, RT, $20 \mathrm{~min}$; (iii) $\mathrm{CO}, 1 \mathrm{~atm}, \mathrm{THF}, 40^{\circ} \mathrm{C}, 7 \mathrm{~h}$; (iv) Ar, THF, $60^{\circ} \mathrm{C}$, $6 \mathrm{~h}$.

to give a yellow product 4 which, in the absence of $\mathrm{CO}$, quickly reverts to the red starting material. Stirring yellow 4 under an atmosphere of $\mathrm{CO}$ for $24 \mathrm{~h}$ or heating it at $40{ }^{\circ} \mathrm{C}$ under $\mathrm{CO}$ for $7 \mathrm{~h}$ resulted in the $\mathrm{CO}$ insertion product $\left[\mathrm{Ir}_{4}(\mathrm{CO})_{8}\left\{\mathrm{C}(\mathrm{O}) \mathrm{CH}_{3}\right\}\left(\mu_{4}-\eta^{3}-\mathrm{Ph}_{2} \mathrm{PCCPh}\right)\left(\mu-\mathrm{PPh}_{2}\right)\right], \quad \mathbf{5}$ (Scheme 1). This compound is stable under $\mathrm{Ar}$, however when heated in THF, at $60{ }^{\circ} \mathrm{C}$, under $\mathrm{Ar}$, for $6 \mathrm{~h}$, it looses $\mathrm{CO}$ to give 2 quantitatively. This behaviour is in contrast with that observed for the acyl cluster $\left[\mathrm{Os}_{3}(\mathrm{CO})_{10^{-}}\right.$ $\left.(\mu-\mathrm{I})\left\{\mathrm{C}(\mathrm{O}) \mathrm{CH}_{3}\right\}\right]$ which, in the absence of $\mathrm{CO}$, reacts to give, not only the $\mathrm{CO}$ de-insertion product, $\left[\mathrm{Os}_{3}(\mathrm{CO})_{10}(\mu-\mathrm{I}) \mathrm{CH}_{3}\right]$, but also $\left[\mathrm{Os}_{3}(\mathrm{CO})_{10}(\mu-\mathrm{I})\left\{\mu_{2}-\eta^{2}-\right.\right.$ $\left.\left.\mathrm{C}(\mathrm{O}) \mathrm{CH}_{3}\right\}\right]$ as the result of a change in the co-ordination mode of the acyl ligand from terminal to bridging ${ }^{11}$. Compound 5 was fully characterised by analytical and spectroscopic data (see Experimental and Table 1) and by an X-ray diffraction analysis.

\section{Solution structure of $\mathbf{5}$}

The IR spectrum of $\mathbf{5}$ in the $v_{\mathrm{CO}}$ region shows a weak absorption at $1695 \mathrm{~cm}^{-1}$, characteristic of an acyl group, besides terminal $v_{\mathrm{CO}}$ bands. The ${ }^{1} \mathrm{H}-\mathrm{NMR}$ spectrum consists of a singlet at $\delta 2.43$ attributed to methyl group of the $\mathrm{C}(\mathrm{O}) \mathrm{CH}_{3}$ ligand and a multiplet at $\delta 6.60-8.30$ 
attributed to the $\mathrm{Ph}$ hydrogens. The ${ }^{13} \mathrm{C}\left\{{ }^{1} \mathrm{H}\right\}$ NMR spectrum of 5 enriched with ${ }^{13} \mathrm{CH}_{3}$ exhibits a singlet at $\delta$ 48.43, attributed to the methyl group of the $\mathrm{C}(\mathrm{O}) \mathrm{CH}_{3}$ ligand. The similarity of the ${ }^{31} \mathrm{P}\left\{{ }^{1} \mathrm{H}\right\}$ NMR spectra of $\mathbf{5}$ and 2 with respect to both chemical shifts and JP-P (see Table 1) strongly suggests that the two compounds have very similar structures, only with an acyl group in $\mathbf{5}$ in place of the methyl in $\mathbf{2}$.

\section{Molecular structure of $\mathbf{5}$}

An X-ray diffraction study of compound $\mathbf{5}$ confirms that the solid state structure of $\mathbf{5}$ is very similar to that of $\mathbf{2}$ indeed (Fig. 3). Their crystals are isomorphous (i.e. the two complexes crystallise with extremely similar packing arrangements). Relevant structure parameters are compared to those of $\mathbf{2}$ in Table 2. The major structural difference resides in the $\mathrm{C}(\mathrm{O}) \mathrm{CH}_{3}$ ligand, bonded in place of $\mathrm{CH}_{3}$. Metal-metal bond distances range from 2.656(1) to 2.912(2) $\AA$, the longest bond being edge spanned by the diphenylphosphino ligand, and the butterfly hinge the smallest $[\operatorname{Ir}(1)-\operatorname{Ir}(2) 2.656(1)]$. The structural parameters within the $\mathrm{Ph}_{2} \mathrm{PCCPh}$ ligand conform to the values found for 2: [ $\operatorname{Ir}(1)-\mathrm{C}(22) 2.09(0.01)$ and $\operatorname{Ir}(4)-\mathrm{C}(23) 2.07(0.01) \AA$; $\operatorname{Ir}(2)-\mathrm{C}(22) 2.38(0.01)$ and $\operatorname{Ir}(2)-\mathrm{C}(23) 2.30(0.01) \AA$ and $\operatorname{Ir}(3)-\mathrm{P}(1) 2.29(3) \AA$. The $\mathrm{C}(22)-\mathrm{C}(23) 1.36(2)$ is slightly shorter than the corresponding distance in 2 [1.40(4) $\AA$ ]. The $\mathrm{Ir}-\mathrm{C}\left[\mathrm{C}(\mathrm{O}) \mathrm{CH}_{3}\right]$ distance $[\mathrm{C}(9)-\operatorname{Ir}(4) 2.14(0.01) \AA]$ is the same as the corresponding distance in $\mathbf{2}$, while the $\mathrm{C}=\mathrm{O}$ separation is $1.20(6) \AA$. The $\operatorname{Ir}(4)-C(9)-C(9 M)$ angle of $118(4)^{\circ}$ corresponds to a sp ${ }^{2}$ hybridised atom.

\section{Solution structure of $\mathbf{4}$}

The various attempts at crystallising this compound for an X-ray diffraction analysis only led to crystals of the starting material 2 (under $\mathrm{Ar}$, at $-5^{\circ} \mathrm{C}$ ) or to those of the $\mathrm{CO}$ insertion product 5 (under $\mathrm{CO}$ at $-5^{\circ} \mathrm{C}$ ). As it could not be obtained in its pure form in the solid state, compound $\mathbf{4}$ was characterised only by solution IR and NMR spectroscopies. Terminal $v_{\mathrm{CO}}$ bands and a weak bridging $v_{\mathrm{CO}}$ at $1851 \mathrm{~cm}^{-1}$ were observed in the IR spectrum of $\mathbf{5}$ which is rather different from that of $\mathbf{2}$ (see Experimental).

The room temperature ${ }^{1} \mathrm{H}-\mathrm{NMR}$ spectrum of 4 in $\mathrm{CD}_{2} \mathrm{Cl}_{2}$ consists a multiplet at $\delta 6.50-7.60$ attributed to the phenyl groups and of a very broad peak at about $\delta 0.7$ possibly due to a methyl group; peaks at $\delta 1.28$ and 2.43 due to small amounts of compounds $\mathbf{2}$ and $\mathbf{5}$ were also noted. As this spectrum suggested some kind of fluxionality, the ${ }^{1} \mathrm{H},{ }^{31} \mathrm{P}\left\{{ }^{1} \mathrm{H}\right\}$ and ${ }^{13} \mathrm{C}\left\{{ }^{1} \mathrm{H}\right\}$ NMR spectra of 4 were investigated at 298, 273 and $190 \mathrm{~K}$ and are shown in Figs. 4 and 5.

The limiting ${ }^{31} \mathrm{P}\left\{{ }^{1} \mathrm{H}\right\}$ NMR spectrum of $\mathbf{4}$ in $\mathrm{CD}_{2} \mathrm{Cl}_{2}$, at $190 \mathrm{~K}$ displays two sets of signals of approximate relative intensities 8:1 consisting of two doublets at $\delta-13.2$ and $136.7\left(\mathrm{JP}_{\mathrm{P}-\mathrm{P}}=18 \mathrm{~Hz}\right)$ assigned to compound $\mathbf{4 A}$, and two peaks at $\delta 0.1(\mathrm{~d}, \mathrm{JP}-\mathrm{P}=24 \mathrm{~Hz})$ and $127.9\left(\mathrm{dd}, \mathrm{JP}_{\mathrm{P}} \mathrm{C}=13 \mathrm{~Hz}\right)$ assigned to compound $\mathbf{4 B}$, besides peaks due to small amounts of compounds $\mathbf{2}$ and $\mathbf{5}$. In both cases, the high frequency peaks were attributed to the phosphido P2 and the other ones to the $\mathrm{Ph}_{2} \mathrm{PCCPh} \mathrm{P} 1$ nuclei. As the temperature is raised all signals broaden and the room temperature spectrum shows only two broad singlets at $\delta$ -14.4 and 134.9. The limiting ${ }^{13} \mathrm{C}\left\{{ }^{1} \mathrm{H}\right\}$ NMR spectrum of a sample of 4 enriched with ${ }^{13} \mathrm{CH}_{3}$ in $\mathrm{CD}_{2} \mathrm{Cl}_{2}$, at $190 \mathrm{~K}$ consists of a singlet at $\delta-36.7$ and a doublet at $-26.8\left(\mathrm{~J}_{\mathrm{C}-\mathrm{P}}\right.$

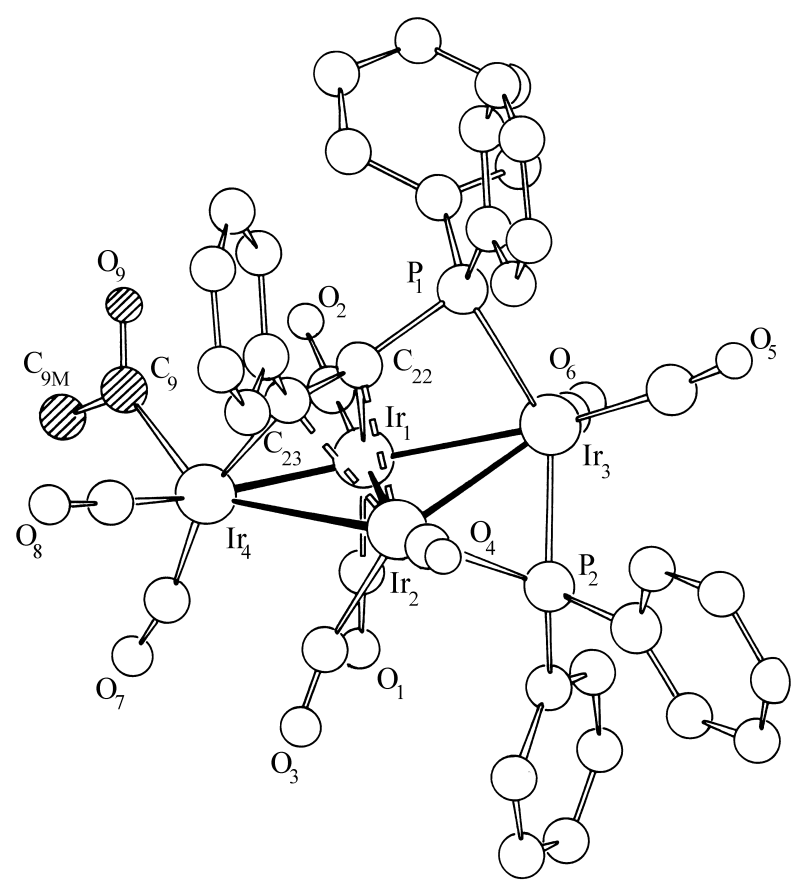

Figure 3. Molecular structure of $\left[\mathrm{Ir}_{4}(\mathrm{CO}){ }_{8}\left\{\mathrm{C}(\mathrm{O}) \mathrm{CH}_{3}\right\}\left(\mu_{4}-\eta^{3}\right.\right.$ $\left.\left.\mathrm{Ph}_{2} \mathrm{PCCPh}\right)\left(\mu-\mathrm{PPh}_{2}\right)\right], 5$.

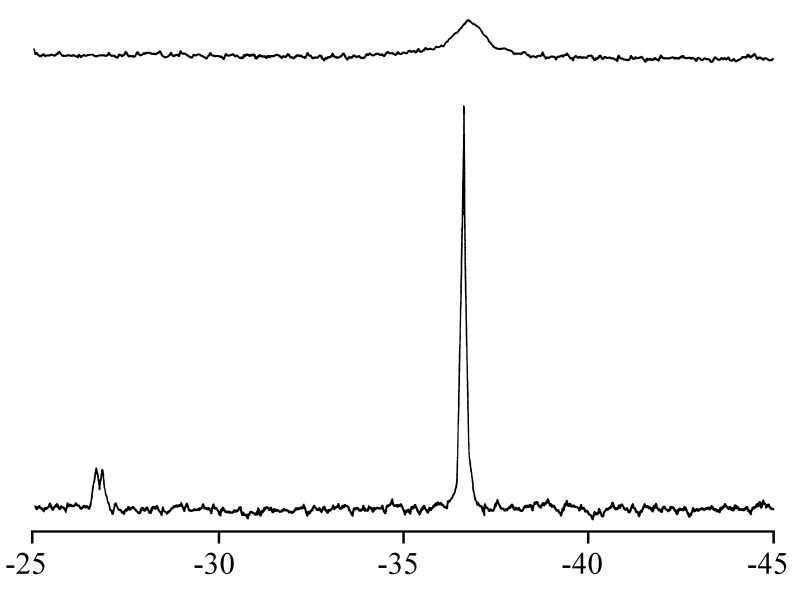

Figure 4. VT ${ }^{13} \mathrm{C}\left\{{ }^{1} \mathrm{H}\right\}$ NMR spectra of isomers $4 \mathrm{~A}$ and $4 \mathrm{~B}$ in the methyl region. 


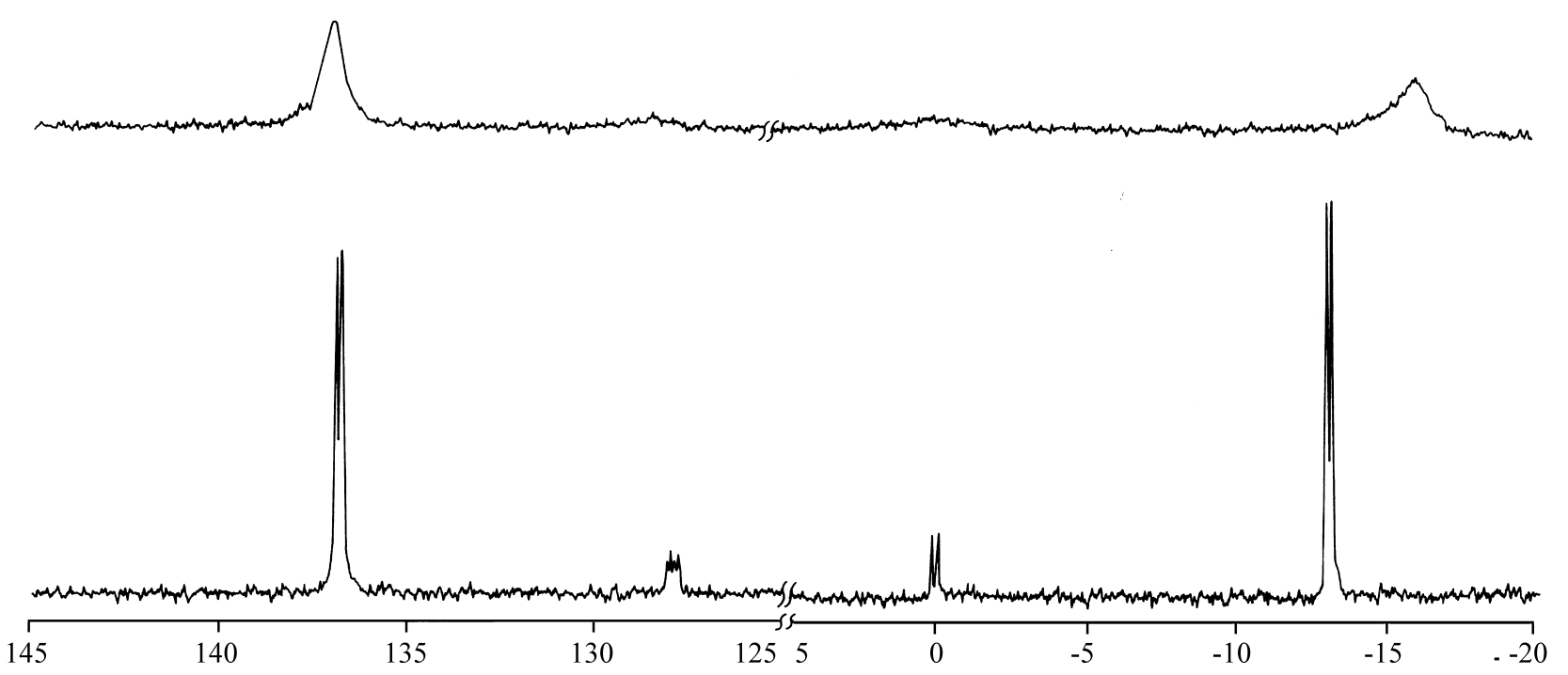

Figure 5. $\mathrm{VT}^{31} \mathrm{P}\left\{{ }^{1} \mathrm{H}\right\}$ NMR spectra of isomers $\mathbf{4 A}$ and $\mathbf{4 B}$.

$=13 \mathrm{~Hz}$ ) assigned to the methyl groups of compound $\mathbf{4 A}$ and $\mathbf{4 B}$, respectively. As the samples were not enriched with ${ }^{13} \mathrm{CO}$, and due to solubility problems, the carbonyl and phenyl regions could not be studied. Raising the temperature also led to the broadening of these resonances, and the room temperature spectrum shows only a broad peak at $\delta-36.10$.

The limiting ${ }^{1} \mathrm{H}-\mathrm{NMR}$ spectrum of the same sample of 4 at $183 \mathrm{~K}$ shows only one doublet at $\delta 0.71\left(\mathrm{~J}_{\mathrm{H}-\mathrm{C}}=120.8\right.$ $\mathrm{Hz}$ ) assigned to the methyl group of $\mathbf{4 A}$, besides signals due to the phenyl protons at $\delta 8.16-5.34$; the fact that the signal due to isomer 4B could not be observed might be due, not only to its low concentration (additionally, the protons would couple both with the carbon and P2), but also because the region was not totally free of impurities. Furthermore, no signal was detected in the acyl region $(\delta$ 2.43 for $\mathbf{5}$ ) which is an indication that $\mathbf{4 A}$ and $\mathbf{4 B}$ are the products from the addition of one or more $\mathrm{CO}$ molecules to 2.

The VT ${ }^{13} \mathrm{C}\left\{{ }^{1} \mathrm{H}\right\}$ and ${ }^{31} \mathrm{P}\left\{{ }^{1} \mathrm{H}\right\}$ NMR spectra show that 4A and $\mathbf{4 B}$ undergo inter-conversion, therefore suggesting that the two compounds are isomers. The fact that the 64 electron hydrido species $\mathbf{3}$ does not undergo $\mathrm{CO}$ addition under the same conditions ${ }^{29}$ strongly suggests that $\mathbf{4 A}$ and 4B result from the addition of a single $\mathrm{CO}$ to the 62 electron compound 2 . The drastic changes observed both in the ${ }^{31} \mathrm{P}$ chemical shifts and in the JP1-P2 values indicate that the CO addition to the metal polyhedron of $\mathbf{2}$ leads to important structural changes involving both $\mathrm{Ph}_{2} \mathrm{PCCPh}$ and $\mu-\mathrm{PPh}_{2}$ ligands (see Table 1). Thus, the 64 electron clusters " $\left[\mathrm{Ir}_{4}(\mathrm{CO}) 9\left(\mathrm{CH}_{3}\right)\left(\mu_{4}-\eta^{3}-\mathrm{Ph}_{2} \mathrm{PCCPh}\right)\left(\mu-\mathrm{PPh}_{2}\right)\right]$ ", $4 \mathbf{A}$ and 4B, would be analogous to 3 , that is they must exhibit a distorted butterfly metal frame without one of the wing edges, however, it is clear, from the ${ }^{31} \mathrm{P}-\mathrm{NMR}$ data, that the missing edge in the polyhedron of $\mathbf{4 A}$ and $\mathbf{4 B}$ is different from that in $\mathbf{3}$. Indeed, whilst the metal atoms bridged by the phosphido group [ $\operatorname{Ir}(2)$ and $\operatorname{Ir}(3)]$ do not interact in $\mathbf{3}(\delta$ 29.8), in $\mathbf{4 A}$ and $\mathbf{4 B}$ they do ( $\delta 136.7$ and 127.9, respectively). As in the precursor 2 the two electron deficient sites are $\operatorname{Ir}(1)$ and $\operatorname{Ir}(4)$, it seems reasonable to suggest that nucleophilic attack of the $\mathrm{CO}$ may have occurred at either positions, leading, in both cases, to the cleavage of the $\operatorname{Ir}(1)-\operatorname{Ir}(4)$ bond, as illustrated in Scheme 2. This metal frame opening was accompanied by a decrease in the $\mathrm{P}(1)-\operatorname{Ir}(3)-\mathrm{P}(2)$ angle, as indicated by the decrease in the $\mathrm{J}_{\mathrm{P} 1-\mathrm{P} 2}$ values from $193 \mathrm{~Hz}\left(135.6^{\circ}\right)$ in the precursor 2 to 18 and $24 \mathrm{~Hz}$ in isomers $\mathbf{4 A}$ and $\mathbf{4 B}$, respectively, close to the value observed for the hydride $\mathbf{3}\left(42.2 \mathrm{~Hz} ; 103.3^{\circ}\right)$. These data suggest that $\mathrm{CO}$ addition to $\mathbf{2}$ has led to a rearrangement of the $\mu_{4}-\eta^{3}-\mathrm{Ph}_{2} \mathrm{PCCPh}$ ligand, which is proposed to interact with the metal frame of $\mathbf{4 A}$ and $\mathbf{4 B}$ as in the hydride $\mathbf{3}$. The two isomers $\mathbf{4 A}$ and $\mathbf{4 B}$ would only differ with respect to the position of the $\mathrm{CH}_{3}$ ligand on the $\operatorname{Ir}(4)$ atom. In $\mathbf{4 B}$, this ligand would occupy a transoid

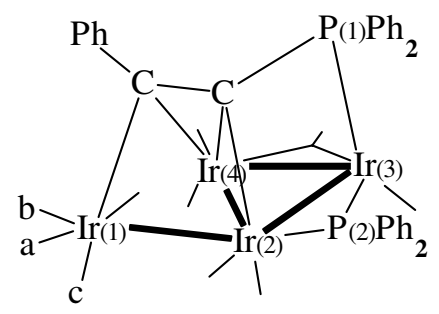

\section{A, 4B}

Scheme 2. Possible structures for the two isomers of " $\left[\mathrm{Ir}_{4}(\mathrm{CO}) 9\left(\mathrm{CH}_{3}\right)\left(\mu_{4}-\right.\right.$ $\left.\left.\eta^{3}-\mathrm{Ph}_{2} \mathrm{PCCPh}\right)\left(\mu-\mathrm{PPh}_{2}\right)\right]^{\prime}: \mathbf{4 A}, \mathrm{CH}_{3}$ in positions b or $\mathrm{c}$ and $\mathbf{4 B}, \mathrm{CH}_{3}$ in position a. 
position with respect to the phosphide $\mathrm{P}(2)$ (position $\mathbf{a}$ in Scheme 2), as suggested by the 3 bond JP2-C $=13 \mathrm{~Hz}$. In compound $4 \mathrm{~A}$, the $\mathrm{CH}_{3}$ ligand could occupy positions $b$ or c which do not favour geometrically this coupling.

Reactions of 2 with $\mathrm{P}(\mathrm{OMe})_{3}$ and $\mathrm{PPh}_{3}$

In order to find out whether nucleophiles other than $\mathrm{CO}$, such as tertiary phosphines and phosphites, would induce migratory $\mathrm{CO}$ insertion in cluster $\mathbf{2}$, as observed for various mononuclear systems ${ }^{30}$, and also in an attempt to determine the possible sites of nucleophilic attack on this cluster, the reactions of 2 with one equivalent of $\mathrm{PPh}_{3}$ and $\mathrm{P}(\mathrm{OMe})_{3}$ were investigated. In both cases the reactions proceed in $\mathrm{CH}_{2} \mathrm{Cl}_{2}$, at room temperature, to yield the green $\mathrm{CO}$ substitution species, $\left[\mathrm{Ir}_{4}(\mathrm{CO})_{7} \mathrm{~L}\left(\mathrm{CH}_{3}\right)\left(\mu_{4}-\eta^{3}-\mathrm{Ph}_{2} \mathrm{PCCPh}\right)(\mu\right.$ $\left.\left.\mathrm{PPh}_{2}\right)\right]\left(\mathrm{L}=\mathrm{PPh}_{3} 6\right.$ and $\left.\mathrm{P}(\mathrm{OMe})_{3} 7\right)$, instead of the expected $\mathrm{CO}$ inserted products. Compounds $\mathbf{6}$ and $\mathbf{7}$ were isolated, after purification by TLC, in 35 and $25 \%$ yields, respectively, besides some unreacted starting material (around $20 \%$ ); in both reactions, a fair amount of decomposition material was noted on the base line of the TLC plates. It is interesting that, only in the case of the reaction with $\mathrm{P}(\mathrm{OMe})_{3}$, an initial colour change occurs, from red to yellow, which only lasts for a few seconds, before the solution turns dark green. This observation suggests formation of a transient $\mathrm{P}(\mathrm{OMe})_{3}$ addition intermediate of the type " $\left[\mathrm{Ir}_{4}\left(\mathrm{CH}_{3}\right)(\mathrm{CO})_{8}\left\{\mathrm{P}(\mathrm{OMe})_{3}\right\}\left(\mu_{4}-\eta-\eta^{3}-\right.\right.$ $\left.\left.\mathrm{Ph}_{2} \mathrm{PCCPh}\right)\left(\mu-\mathrm{PPh}_{2}\right)\right]$ ", possibly analogous to the yellow $\mathrm{CO}$ addition intermediate 4 . Compound $\mathbf{7}$ was characterised only by IR spectroscopy as it undergoes decomposition in solution. The $\mathrm{PPh}_{3}$ derivative was characterised by spectroscopic and analytical data (see Experimental and Table 1), however, suitable crystals for an X-ray analysis could not be obtained.

The IR spectra of $\mathbf{6}$ and $\mathbf{7}$ are very similar and show the presence of only terminal CO ligands; compared to the spectrum of compound $\mathbf{2}$, both spectra are shifted towards lower $v_{\mathrm{CO}}$ by about $15 \mathrm{~cm}^{-1}$, as expected for a $\mathrm{CO}$ mono-substitution. The ${ }^{1} \mathrm{H}-\mathrm{NMR}$ spectrum of $\mathbf{6}$ in $\mathrm{CDCl}_{3}$ at $22{ }^{\circ} \mathrm{C}$ contains signals assigned to phenyl groups and to two cluster bound methyl groups at $\delta 0.28$ and 0.43 , of approximate intensities 1:1, suggesting the presence of two isomers.

The room temperature ${ }^{31} \mathrm{P}\left\{{ }^{1} \mathrm{H}\right\}$ NMR spectrum of 6 consists of two sets of three signals with relative intensities $1: 1$, thus confirming that the compound exists as a mixture of two isomers, $\mathbf{6 A}$ and $\mathbf{6 B}$. The $\mathrm{P} 1$ nucleus $\left(\mathrm{Ph}_{2} \mathrm{PCCPh}\right)$ in 6A and $6 \mathrm{~B}$ appears at $\delta-52.2\left(\mathrm{~J}_{\mathrm{P} 1-\mathrm{P} 2}=228 ; \mathrm{J}_{\mathrm{P} 1-\mathrm{P} 3}=13 \mathrm{~Hz}\right)$ and $-41.90\left(\mathrm{~J}_{\mathrm{P} 1-\mathrm{P} 2}=189\right.$ and $\left.\mathrm{J}_{\mathrm{P} 1-\mathrm{P} 3}=10 \mathrm{~Hz}\right)$, respectively, and $\mathrm{P} 2\left(\mu-\mathrm{PPh}_{2}\right)$ in $\mathbf{6 A}$ and $\mathbf{6 B}$ appears at $\delta 77.30(\mathrm{~J} \mathrm{P} 1-\mathrm{P} 3=$ $10 \mathrm{~Hz}) \delta 65.9$, respectively. A comparison of these chemical shifts and JP1-P2 values with those observed for 2

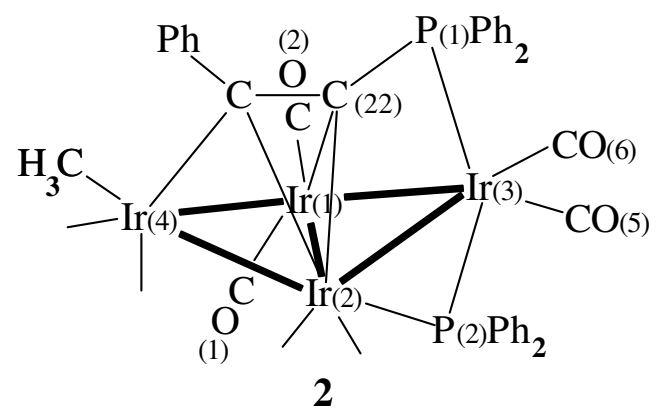

Scheme 3. Possible structures for isomers 6A and 6B of $\left[\mathrm{Ir}_{4}(\mathrm{CO})_{7}\left(\mathrm{PPh}_{3}\right)\left(\mathrm{CH}_{3}\right)\left(\mu_{4}-\eta^{3}-\mathrm{Ph}_{2} \mathrm{PCCPh}\right)\left(\mu-\mathrm{PPh}_{2}\right)\right]$ : 6A, $\mathrm{PPh}_{3}$ in place of $\mathrm{CO}(5)$ or $\mathrm{CO}(6)$ and $6 \mathrm{~B}, \mathrm{PPh}_{3}$ in place of $\mathrm{CO}(1)$.

$(\delta-47.2, \mathrm{P} 1$ and 73.8, $\mathrm{P} 2 ; \mathrm{JP} 1-\mathrm{P} 2=193 \mathrm{~Hz})$ suggests that the basic phosphorus ligands arrangement in $\mathbf{2}$ is maintained in both isomers. The fact that the $\mathrm{P}(1)-\operatorname{Ir}(3)-\mathrm{P}(2)$ angle seems to have been more disturbed in $\mathbf{6 A}$ than in $\mathbf{6 B}$, and that $\mathrm{P} 3$ $\left(\mathrm{PPh}_{3}\right)$ in isomer $6 \mathrm{~A}(\delta$ 13.7) couples with both $\mathrm{P} 2$ and $\mathrm{P} 1$ $(\sim 13 \mathrm{~Hz})$, whilst in $\mathbf{6 B}(\delta-9.1)$ it only couples with P1 (10 $\mathrm{Hz}$ ), tends to indicate that $\mathrm{PPh}_{3}$ is bonded to $\operatorname{Ir}(3)$ in $\mathbf{6 A}$ and to $\operatorname{Ir}(1)$ in $6 \mathrm{~B}$ (see Scheme 3). Assuming that the CO ligands disposition on the metal polyhedron of $\mathbf{2}$ remains the same upon substitution of a $\mathrm{CO}$ for a $\mathrm{PPh}_{3}$, as is often the case, it is possible to propose plausible structures for isomers $6 \mathrm{~A}$ and $\mathbf{6 B}$, based on a correlation between the phosphorus nuclei coupling constants in $\mathbf{2}, \mathbf{6 A}$ and $\mathbf{6 B}$ and specific dihedral angles in $\mathbf{2}$. In the case of isomer $\mathbf{6 A}$, the $\mathrm{PPh}_{3}$ on $\operatorname{Ir}(3)$ could occupy the positions of either $\mathrm{CO}(5)$ or $\mathrm{CO}(6)$. It is impossible to differentiate between the two possibilities, as $\mathrm{P}(1)-\operatorname{Ir}(3)-\mathrm{C}(5)\left[95.5(0.4)^{\circ}\right]$ and $\mathrm{P}(1)-\operatorname{Ir}(3)-\mathrm{C}(6)\left[102.0(0.4)^{\circ}\right]$ on the one hand and $\mathrm{P}(2)-\operatorname{Ir}(3)-\mathrm{C}(5)\left[100.4(0.4)^{\circ}\right]$ and $\mathrm{P}(2)-\operatorname{Ir}(3)-\mathrm{C}(6)$ $\left[109.9(0.4)^{\circ}\right]$ on the other hand would lead to similar $\mathbf{J}$ values. In the case of isomer $\mathbf{6 B}$, calculated values for the $\left[\mathrm{C}(1)-\operatorname{Ir}(1)-\mathrm{C}(22)-\mathrm{P}(1), \quad 129.4^{\circ}\right] \quad$ and $\left[C(2)-\operatorname{Ir}(1)-C(22)-P(1), 75 .{ }^{\circ}\right]$ dihedral angles of compound 2 (see Fig. 1) suggest that the $\mathrm{PPh}_{3}$ (P3) could occupy the positions of either $\mathrm{CO}(1)$ or $\mathrm{CO}(2)$ and couple with the $\mathrm{Ph}_{2} \mathrm{PCCPh}(\mathrm{P} 1)$ ligand. As no JP2-P3 is observed in the spectrum of this isomer, the calculated values for the $\left[\mathrm{C}(1)-\operatorname{Ir}(1)-\operatorname{Ir}(2)-\mathrm{P}(2), 63.9^{\circ}\right]$ and $[\mathrm{C}(2)-\operatorname{Ir}(1)-\operatorname{Ir}(2) \mathrm{P}(2)$, $143.3^{\circ}$ ] dihedral angles strongly suggest that replacement of pseudo-axial $\mathrm{CO}(1)$ in 2 with $\mathrm{PPh}_{3}$ is most probable.

Considering that $\operatorname{Ir}(1)$ and $\operatorname{Ir}(4)$ are the electron deficient metal centres of compound 2 (vide supra), nucleophilic attack of $\mathrm{L}\left[\mathrm{L}=\mathrm{PPh}_{3}\right.$ or $\left.\mathrm{P}(\mathrm{OMe})_{3}\right]$ could be expected to occur at either position to yield $\mathrm{L}$ addition, $\mathrm{CO}$ substitution or even $\mathrm{CO}$ insertion products. Although migratory $\mathrm{CO}$ insertion is usually the preferred path in mononuclear chemistry ${ }^{10,30}$, not a single example involving a carbonyl cluster has been described in the literature yet. Our work indicates a clear preference for the 
CO substitution path which, in the case of the reaction with $\mathrm{P}(\mathrm{OMe})_{3}$, seems to occur via formation of a transient $\mathrm{P}(\mathrm{OMe})_{3}$ adduct. In other words, in this system, $\mathrm{CO}$ dissociation from the adduct is faster than $\mathrm{CO}$ migratory insertion. Finally, contrarily to expectation, isomer $\mathbf{6 A}$ contains the $\mathrm{PPh}_{3}$ ligand bonded to $\operatorname{Ir}(3)$, instead of $\operatorname{Ir}(4)$. It is possible that ligand rearrangement occurred, after addition of L, or even after CO substitution. Recent studies have evidenced that migration of phosphine ligands on cluster compounds is not an uncommon process ${ }^{31,32}$.

\section{Concluding Remarks}

The lability of compound $\mathbf{2}$ might be associated with the charge imbalance in the cluster, which would favour nucleophilic attack of $\mathrm{CO}$ or phosphines at one of the electron poor metal centres, to yield addition products. In contrast with mononuclear 18 electron species, cluster compounds can accommodate additional ligands via cleavage of M-M bonds. In this context, the role of the $\mu_{4}-\eta^{3}-\mathrm{Ph}_{2} \mathrm{PCCPh}$ bridging ligand is crucial in maintaining the metal atoms together and in inducing the polarisation of the Ir-Ir bonds.

\section{Acknowledgement}

We thank FAPESP, PADCT and CNPq of Brazil (F.Y.F., M.D.V. and R. M.S.P.) and the Ministero della Universitá e della Ricerca Scientifica e Tecnologica of Italy (D.B. and F.G.) for research grants

\section{References}

1. Hoffmann, R. Angew. Chem. Int. Ed. Engl. 1982, 21, 711.

2. Bau, R.; Chiang, M.Y. ; Wei, C-Y; Garlaschelli, L.; Martinengo, S.; Koestzle, T.F. Inorg. Chem. 1984, 23, 4758.

3. Ragaini, F.; Porta, F.; Demartin, F. Organometallics 1991, 10, 185.

4. Albano, V.G.; Canziani, F.; Ciani, G.; Chini, P.; Martinengo, S.; Manassero, M.; Giordano, G. J. Organomet. Chem. 1978, 150, C17.

5. Chinara, T.; Aoki, K.; Yamazaki, H. J. Organomet. Chem. 1990, 383, 367.

6. Chinara, T.; Aoki, K.; Yamazaki, H. J. Organomet. Chem. 1994, 473, 273.

7. González-Moraga. In Cluster Chemistry, Chapter 3, Springer-Verlag, Berlin, 1993.

8. Benvenutti, M.H.A.; Vargas, M.D.; Braga, D.; Grepioni, F.; Parisini, E.; Mann, B.E. Organometallics 1993, 12, 2955.
9. Benvenutti, M.H.A.; Vargas, M.D.; Braga, D.; Grepioni, F.; Mann, B.E.; Naylor, S. Organometallics 1993, 12, 2947.

10. Yamamoto, A. In Organotransition Metal Chemistry, Wiley, 1986.

11. Morison, E.D.; Bassner, L.S. L.; Geoffroy, G.L. Organometallics 1986, 5, 408.

12. Pereira, R.M.S.; Fujiwara, F.Y.; Vargas, M.D.; Braga, D.; Grepioni, F. Organometallics 1997, 16, 4833.

13. Delgado, E.; Chi, Y.; Wang, W.; Horgath, G.; Low, P.J.; Enright, G.D.; Peng, S.-M.; Lee, G.-H.; Carty, A.J. Organometallics 1998, 17, 2936.

14. Vargas, M.D.; Pereira, R.M.S.; Braga, D.; Grepioni, F. J. Chem. Soc. Chem. Commun. 1993, 1008.

15. Hengefelt, A.; Nast, R. Chem. Ber. 1983, 116, 2025.

16. Livotto, F.S.; Raithby, P.R.; Vargas, M. D. J. Chem. Soc. Dalton Trans. 1993, 1797.

17. Brauer, G. Handboock of Preparative Inorganic Chemistry, 1965, 1, 645.

18. Sheldrick, G.M. Acta Crystallogr. 1990, A46, 467.

19. Sheldrick, G.M. SHELX76, Program for Crystal Structure Determination; University of Cambridge, Cambridge, England, 1976.

20. Walker, N.; Stuart, D. Acta Crystallogr., Sect. B 1983, 39, 158.

21. Keller, E. SHAKAL92, Graphical Representation of Molecular Models; University of Freiburg, FRG, 1992.

22. Kubota, M.; McClesky, T.M.; Hayashi, R.K.; Carl, G. J. Am. Chem. Soc. 1987, 109, 7569.

23. Wade, K. Adv. Inorg. Chem. Radiochem. 1976, 18, 1.

24. Benvenutti, M.H.A.; Vargas, M.D.; Hitchcock, P.B.; Nixon, J.F. J. Chem. Soc. Chem. Commun. 1995, 866.

25. Carty, A.J.; Mac Laughlin, S.A.; Nucciaroni, D. Phosphorus 31-NMR Spectroscopy In Steereochemical Analysis of Organic Compounds and Metal Complexes, Chapter 16; Verkade, J. G.; Quin, L. D. Eds; VCH, 1987.

26. Keister, J.B. J. Organomet. Chem. 1980, 190, C36.

27. Aime, S.; Dastrù, W.; Gobetto, R.; Viale, A. Organometallics 1998, 17, 3182.

28. Johnson, B.F.G.; Lewis, J.; Orpen, A.G.; Raithby, P.R.; Süss, G. J. Organomet. Chem. 1979, 173, 187.

29. Araujo, M.H.; Vargas, M. D. unpublished results.

30. a) Monti, D.; Frachey, G.; Bassetti, M.; Haynes, A.; Sunley, G.J.; Maitlis, P.M.; Cantoni, A.; Bocelli, G. Inorg. Chim. Acta 1995, 240, 485; b) Garcia Alonso, J.; Llamazares, A.; Riera, V.; Díaz, M. R.; García Grande, S. J. Chem. Soc. Chem. Commun. 1991, 1058; c) Cotton, J.D.; Crisp, G.T.; Daly, V. A. Inorg. Chim. Acta 1981, 47, 165. 
31.a) Bondietti, G.; Laurenczy, G, Ross, R.; Roulet, R. Helv. Chim. Acta 1994, 77, 1869. b) Laurenczy, G; Bondietti, G.; Merbach, A.E.; Moulet, B.; Roulet, R. Helv. Chim. Acta 1994, 77, 547.
32. Braga, D.; Grepioni, F.; Vargas, M. D.; Ziglio, C. M. manuscript in preparation.

Received: December 10, 1998 